1 Long-term effects of increasing omega-3, omega-6 and total polyunsaturated fats on

inflammatory bowel disease and markers of inflammation: A Systematic Review and Meta-

5 Sarah M. Ajabnoor ${ }^{1,2^{*}}$, Gabrielle Thorpe ${ }^{3 * *}$, Asmaa Abdelhamid $^{1 * *}$, and Lee Hooper ${ }^{1 * *}$

6

${ }^{1}$ Norwich Medical School, University of East Anglia, Norwich Research Park, UK.

${ }^{2}$ Clinical Nutrition Department, Faculty of Applied Medical Sciences, Jeddah, King Abdulaziz

University, Saudi Arabia

${ }^{3}$ School of Health Sciences, University of East Anglia, Norwich Research Park, UK.

${ }^{*}$ Corresponding author: Sarah M. Ajabnoor, Clinical Nutrition Department, Faculty of Applied Medical Sciences, King Abdulaziz University, P.O. Box 80324, Jeddah, 21589, Kingdome of Saudi Arabia,smajabnoor@kau.edu.sa,ORCIDID:0000-0003-0996-1484.

** Gabrielle Thorpe ORCID ID: 0000-0002-0639-4229, Asmaa Abdelhamid ORCID ID: 0000-00029897-5433, Lee Hooper ORCID ID: 0000-0002-7904-3331.

\title{
Acknowledgements and contributions
}

This review is one of a set of reviews conducted by the Polyunsaturated Fats and Health (PUFAH) Group, which includes Asmaa Abdelhamid, Zoya Ahmed, Sarah MA Ajabnoor, Fai K AlAbdulghafoor, Lena Al-Khudairy, Priti Biswas, Julii Suzanne Brainard, Charlene Bridges, Tracey J Brown, Katherine HO Deane, Daisy H Donaldson, Sarah Hanson, Lee Hooper, Oluseyi F Jimoh, Nicole Martin, Katie Maas, Helen J Moore, Alex T O’Brien, Karen Rees, Ruksana Sivakaran, Fujian Song, Carolyn D Summerbell, Gabrielle C Thorpe, Xia Wang, Ailsa Welch, Lauren Winstanley, and Helen V Worthington.

The authors' responsibilities were as follows: SMA, GT, AA, and LH designed the study. LH and AA developed and ran the searches. All authors and other members of the PUFAH Group including Zoya Ahmed screened studies and trial registers for eligibility and extracted data. SMA, GT, 
32 AA, and LH input data into RevMan, conducted the statistical analysis, and interpreted the results.

33 SMA, GT, AA, and LH wrote the manuscript. LH carried out GRADE assessment. There are no 34 potential conflicts of interest to be declared.

The review authors thank all of the authors of primary studies who kindly replied to our queries and where possible provided us with the best set of data available, including: YZ Almallah, University

37 of Aberdeen (Almallah 1998); D Kromhout, Wageningen University (AlphaOmega); A Belluzzi, Institute of Clinical Medicine and Gastroenterology, Bologna (Belluzzi 1996); I Dichi, University of Londrina, Brazil (Berbert 2005); 1 Quanjun, Zhengzhou University, China (Bo 2017); J Brox, University Hospital of North Norway (Brox 2001); GE Lobley, The Rowett Institute of Nutrition and Health, University of Aberdeen (Clark 2016); DA de Luis Román, University of Valladolid (de Luis 2016); G Derosa and P Maffioli, University of Pavia (Derosa 2011 \& 2016); PNM Demacker,

43 University Hospital Nijmegen (Deslypere 1992); G Einvik, Akershus University Hospital and H 44 Arnesen, Oslo University Hospital (DO IT 2010); A Sanyal, Virginia Commonwealth University, USA (EPE-A 2014); BG Feagan, University of Western Ontario (EPIC 1 \& 2); Vanessa Danthir, CSIRO Human Nutrition, Adelaide (EPOCH 2014); E Lund, University of East Anglia (FishGastro); G Pierce,

47 St Boniface Hospital Resarch Center, Canada (FLAXPAD); S Greenfield, QEII Hospital, Welwyn 48 Garden City (Greenfield 1993); AB Hawthorne, University Hospital Cardif (Hawthorne 1993); P 49 Sparks, University of Melbourne (Kumar 2008); CS Lau, Queen Mary Hospital, Hong Kong (Lau 1993); R Lorenz, Klinikum Universitat Munchen (Loeschke 1996); P Bauer, Medical University of

51 Vienna (Lorenz-Meyer 1996); W Bemelmans, National Institute for Public Health and Environment 52 (RIVM), Bilthoven, the Netherlands (MARGARIN); T Sanders, Kings College London (MARINA); 53 J Mate-Jiminez, Hospital de la Princesa, Madrid (Mate 1991); JA Heady, MRC Social Research Unit 54 (MRC 1968); D Nilsen, University of Bergen, Norway (OFAMI 2001); Y Freund-Levi, Karolinska 55 Institutet, Sweden (Omega-AD); R Zurier, University of Massachusetts (Reed 2014); A Manni, Penn 56 State College of Medicine, USA (Sandhu 2016); B Akesson, University of Lund (Skoldstam 1992); K 
57 Tande, Calanus AS, Norway (Tande 2016); K Tuttle, Sacred Heart Medical Center, Spokane (THIS

58 DIET 2008); M Vijayakumar, Amrita Institute of Medical Sciences, India (Vijayakumar 2014).

59

\section{$60 \quad$ Funding}

61 This systematic review was one of a set of systematic reviews commissioned by the World Health

62 Organization's Nutrition Guidance Expert Advisory Group (NUGAG) Subgroup on Diet and Health,

63 to inform its guidance on polyunsaturated fatty acid intake. NUGAG requested specific inclusion

64 criteria (including duration of trials and outcomes), some sensitivity analyses and subgroups. The

65 results of the reviews, including GRADE assessments were discussed and reviewed by the WHO

66 NUGAG Subgroup on Diet and Health as part of WHO's guideline development process. WHO was

67 not otherwise involved in writing this report.

68

69 


\section{Abstract}

71 Background \& Aims: Effects of long-chain omega-3 (LCn3) and omega-6 fatty acids on prevention

72 and treatment of inflammatory bowel diseases (IBD, including Crohn's Disease, CD and ulcerative

73 colitis, UC), and inflammation are unclear. We systematically reviewed long-term effects of omega-

74 3, omega-6 and total polyunsaturated fats (PUFA) on IBD diagnosis, relapse, severity, 75 pharmacotherapy, quality of life and key inflammatory markers.

76 Methods: We searched Medline, Embase, Cochrane CENTRAL, and trials registries, including RCTs

77 in adults with or without IBD comparing higher with lower omega-3, omega-6 and/or total PUFA

78 intake for $\geq 24$ weeks that assessed IBD-specific outcomes or inflammatory biomarkers.

79 Results: We included 83 RCTs (41,751 participants), of which 13 recruited participants with IBD. 80 Increasing LCn3 may reduce risk of IBD relapse (RR $0.85,95 \%$ CI 0.72 to 1.01 ) and IBD worsening 81 (RR $0.85,95 \%$ CI 0.71 to 1.03 ), and reduce erythrocyte sedimentation rate (ESR, SMD $-0.23,95 \%$ CI

$82-0.44$ to -0.01 ), but may increase IBD diagnosis risk (RR 1.10, 95\% CI 0.63 to 1.92 ), and faecal 83 calprotectin, a specific inflammatory marker for IBD (MD 16.1 $\mathrm{g} / \mathrm{g}, 95 \%$ CI -37.6 to 69.8, all low84 quality evidence). Outcomes for alpha-linolenic acid, omega-6 and total PUFA were sparse, but 85 suggested little or no effect where data were available.

86 Conclusion: This is the most comprehensive meta-analysis of RCTs investigating long-term effects

87 of omega-3, omega- 6 and total PUFA on IBD and inflammatory markers. Our findings suggest that 88 supplementation with PUFAs has little or no effect on prevention or treatment of IBD and provides 89 little support for modification of long-term inflammatory status.

91 Keywords: Inflammatory bowel diseases; Dietary fats, unsaturated; Fatty acids, omega-3; Fatty

92 acids, omega-6; Alpha-linolenic acid; meta-analysis

93 


\section{Introduction}

Crohn's Disease (CD) and ulcerative colitis (UC), collectively 'inflammatory bowel disease'

(IBD), are inflammatory conditions of the gastrointestinal tract. While CD and UC share relapsing-

remitting progression and chronic mucosal inflammation, they are distinct in clinical presentation and

outcomes. Precise aetiologies of CD and UC are unclear, although environmental, gut microbiome,

99 immune response and genetic factors predispose individuals to IBD [1]. A recent systematic review 100 suggests that IBD prevalence is over $0.3 \%$ in North America, Oceania and many European countries, 101 with lower but rising incidence in newly industrialised African, Asian, and South American countries 102 [2]. IBD is expensive to individuals and healthcare systems, and has serious impacts on quality of life $103[3,4]$. The primary goal in clinical management of UC and CD is to induce and maintain remission 104 [5]. Secondary goals include minimising IBD's psychosocial impact, physical distress and depressive 105 symptoms associated with relapse [6]. Reducing need for pharmacological maintenance (including corticosteroids, immune-suppressants and immunomodulatory medications) may be helpful as these drugs are associated with significant adverse events [7].

Polyunsaturated fatty acids (PUFAs) include omega-3 and omega-6 fatty acids. Long-chain omega-3 fatty acids (LCn3) include eicosapentaenoic acid (EPA) and docosahexaenoic acid (DHA),

110 found in fish; while alpha-linolenic acid (ALA) is found in some plant oils (including flaxseed, some 111 nuts and rapeseed/canola). Many plant oils are rich in omega-6 fats, particularly linoleic acid (LA). 112 LCn3 are thought to reduce various physiological aspects of inflammation including leucocyte 113 chemotaxis, adhesion molecule expression, leucocyte-endothelial adhesive interactions, prostaglandin 114 and leukotriene production from omega-6 and production of pro-inflammatory cytokines [8]. Omega1156 (LA) has been correlated with pro-inflammatory effects, and its derivative arachidonic acid (AA) is 116 a precursor for key pro-inflammatory mediators [8, 9]. Earlier case-controlled studies have reported a 117 high levels of AA in mucosal tissues of IBD patients. While data from animal studies shown that the 118 intake of AA have increased the severity of the inflammation in IBD [10]. Thus, LCn3 and ALA may 
119 help maintain remission, prevent or delay diagnosis of IBD, and reduce markers of inflammation, while

120 LA and AA omega-6 fats are considered relatively pro-inflammatory.

121 Inflammation is generally assessed in clinical practice and research by measuring biomarkers.

122 C-reactive protein (CRP) and erythrocyte sedimentation rate (ESR) are used to measure systemic

123 inflammation and are non-specific indicators for IBD [11]. CRP levels correlate better than ESR with

124 IBD clinical activity, are measured more frequently in clinical situations and are less affected by aging

$125[11,12]$. Faecal calprotectin is a promising site-specific biomarker, released within the intestinal 126 mucosa during inflammation, and recommended to support differential diagnosis between IBD and 127 non-IBD gastrointestinal inflammation [5]. Inflammatory cytokines (including interleukin-6 (IL-6) 128 and tumour necrosis factor- $\alpha(\mathrm{TNF}-\alpha)$ ) and adhesion molecules (such as intercellular adhesion 129 molecule 1 (ICAM-1) and vascular cell adhesion molecule 1 (VCAM-1)) are increased in the intestinal 130 mucosa during inflammation and may have a role in disease pathogenesis $[13,14]$. Although plasma 131 IL-6 and CRP correlate with IBD incidence pre-clinically, and may indicate early disease status of 132 IBD [15], they are non-specific markers of inflammation and so are potentially affected by additional 133 variables.

134 Additionally, increasing dietary PUFA inevitably alters the overall balance of nutrient intake 135 and may favourably affect gut microbiota [16]. Despite strong theoretical mechanisms for utility of 136 LCn3 and negative effects of omega- 6 on IBD, the research evidence is contradictory. We aimed to 137 systematically review effects of PUFA (LCn3, ALA, omega-6, total PUFA) on remission and relapse 138 rates, pharmaceutical use, disease severity and incidence, and quality of life as well as key 139 inflammatory markers in long-term trials. We were also interested in how effects varied by UC and $140 \mathrm{CD}$, intervention type, baseline severity, dose, duration and nutrients displaced by increased PUFA. 


\section{Methods}

144 This review is part of a series by the Polyunsaturated Fats and Health (PUFAH) group 145 commissioned by the World Health Organization (WHO) Nutrition Guidance Expert Advisory Group 146 (NUGAG) Subgroup on Diet and Health to inform and contribute to development of WHO 147 recommendations. We collated a large set of long-term trials of PUFAs and examined them for 148 relevant, often unpublished, outcomes [17]. The full set of reviews assesses effects of PUFA on 149 cardiovascular disease, cancers, inflammatory bowel disease, neurocognitive outcomes and depression 150 [17-24]. This systematic review is registered on PROSPERO [25]. Methods for the set of PUFAH 151 reviews were based on Cochrane and GRADE, using Review Manager 5.3 and GradePRO software 152 [26-29], reported according to PRISMA guidelines [30]. Detailed methodology for the set of reviews, 153 the trials database and flow diagram are described elsewhere [17], review methodology is briefly 154 presented here.

\section{Inclusion criteria}

We included published and unpublished randomised controlled trials (RCTs) comparing higher outcomes. Participants were adults (aged $\geq 18$ years) with or without a diagnosis of IBD, but trials of pregnant or acutely ill participants (with current cancer, undergoing transplantation, with acquired 161 immune deficiency syndrome (AIDS) or human immunodeficiency virus (HIV), on haemodialysis, 162 with IgA glomerulonephritis or any renal problem) were excluded. Eligible interventions could be 163 dietary advice; supplementation (taken orally as oil, foods or capsules); or diet provided. 164 Multifactorial interventions were excluded.

Primary outcomes included rates of induced IBD relapse (or remission), IBD severity or worsening and inflammatory markers (CRP, ESR, IL-6 and faecal calprotectin) in studies of people 167 with existing IBD. In other trials primary outcomes included IBD diagnoses and inflammatory 
markers. Secondary outcomes, assessed in included trials were: corticosteroid, immunosuppressant, 169 and immuno-modulator use, measures of quality of life, other inflammatory marker levels and 170 adiposity measures.

\section{Methods for identification of studies}

174 ClinicalTrials.com and the World Health Organization International Clinical Trials Registry Platform 175 to September 2016, and reassessed all ongoing trials in July 2019. We checked included trials of 176 relevant systematic reviews, and wrote to authors of included studies for additional studies and trial 177 data [17], creating a database of trials that randomised participants to increased omega-3, omega-6 or 178 total PUFA compared to lower omega-3, omega- 6 or total PUFA and assessed effects for $\geq 24$ weeks 179 (reflecting metabolic studies suggesting 6 months is the minimum duration of supplementation 180 required to ensure equilibration of LCn3 into most body compartments) [31]. From this database, 181 studies were chosen for this review that had assessed at least one primary review outcome (even when 182 not fully reported).

183 Study inclusion, data extraction and risk of bias were assessed independently in duplicate. We 184 assessed Cochrane risk of bias tool domains [32] as well as risk from compliance problems and 185 attention bias [17]. We considered dietary advice trials to be at low summary risk of bias where we 186 judged randomisation, allocation concealment and blinding of outcome assessors adequate, and 187 supplement trials to be at low summary risk of bias where we judged randomisation, allocation 188 concealment, blinding of participants, personnel and outcome assessors adequate (all other trials were 189 considered at moderate or high risk of bias).

\section{Data synthesis}



using random-effects meta-analysis as dietary interventions are naturally heterogeneous [33].

194 Treatment/control differences in outcomes were combined across studies using relative risks (RR) or 195 mean differences (MD), measures using different units were converted to a single unit. Data on change 196 from baseline in each arm with standard deviations were used for continuous outcomes where 197 available, otherwise endpoint data were used [33]. As remission is the reverse of relapse we assessed 198 these outcomes together, using relapse as the outcome. We ran sensitivity analyses for all primary 199 outcomes using fixed-effect meta-analysis, limiting to studies at low summary risk of bias and at low 200 risk of bias from compliance. Further sensitivity analysis (limiting analyses to trials randomising $\geq 100$ 201 participants), subgrouping and funnel plots were carried out where there were at least ten trials in a 202 meta-analysis. We noted where data were measured but not fully reported to assess potential 203 publication bias, and partially reported data were displayed in forest plots to allow assessment of 204 consistency with meta-analysis results. Heterogeneity was assessed using $\mathrm{I}^{2}$ and considered important 205 where over 50\% [34].

206 Effect sizes were interpreted as agreed with WHO NUGAG and pre-specified for this set of 207 reviews [17]. In conjunction with Cochrane methodology we used the best estimate of effect size 208 (rather than statistical significance) to assess whether effects occurred $[17,26]$. $\mathrm{RR}<0.92$ or $>1.08$ 209 was considered a relevant clinical effect (RR 0.92 to 1.08 was considered "little or no effect"), while 210 mean difference between arms of $\geq 10 \%$ of baseline was required for a relevant clinical effect for 211 continuous measures. Outcome data were interpreted using GRADE assessment, drafted by LH then 212 discussed and agreed with WHO NUGAG [17]. Where GRADE suggested data of very low-quality 213 we did not interpret effect sizes. Where data were of low-quality we used the term "may", moderate214 quality evidence warranted "probably" in describing effect sizes.

\section{Subgroup analysis}


We subgrouped on the basis of intervention type, PUFA dose, trial duration, replacement, age,

218 sex, baseline IBD severity, diagnosis of UC or CD, baseline levels of inflammatory markers and 219 baseline medication use (corticosteroid, immunosuppressant or immuno-modulatory therapies). We 220 were not able to subgroup by baseline PUFA intakes or change in omega-3/omega-6 ratio (as we had 221 planned) as these data were rarely provided. 


\section{Results}

\section{Description of studies}

Brief characteristics, risk of bias assessments and references of included IBD studies are outlined in Table 1, of trials providing data on IBD diagnosis in Table 2, and included trials providing 227 data on inflammatory markers in Table 3, while characteristics of all included studies are detailed in 228 Additional Table 1. Further additional tables, forest plots, funnel plots and details of all sensitivity analyses and subgroups are also found in the Additional Materials.

We included 83 RCTs that measured at least one of our primary outcomes. These 83 RCTs (84 comparison groups) randomised 41,751 participants. Eleven RCTs were assessed as at low summary risk of bias, Additional Figure 1 [35-45]. Forty four trials were conducted in Europe, 18 in North 233 America; 4 in South America; 12 in Asia; 2 in Australia, and three across several continents. Thirteen 234 studies specifically recruited participants with IBD (7 with UC [46-52], 6 with CD [37, 42, 53-55]), 26 had CVD or raised lipids at baseline, 10 had diabetes, metabolic syndrome or raised insulin levels, 11 had rheumatoid arthritis, 4 were overweight or obese, 5 were healthy adults, the remainder other conditions (2 lupus, 2 cognitive problems, 1 dry eyes, 1 mobility problems, 3 non-alcoholic steatohepatitis, 1 various, 1 other arthritis, 1 periodontitis, 1 raised breast density, 1 multiple sclerosis). Seventy trials assessed effects of LCn3, six effects of ALA, and three effects of omega-3 (it was

240 unclear whether LCn3, ALA or both). Seven trials assessed effects of omega-6 compared to something 241 other than omega-3, and two assessed effects of total PUFA (several trials compared more than two 242 relevant arms).

\section{Effects of LCn3 in people with existing IBD}

Increasing LCn3 may reduce the risk of IBD relapse (low quality evidence, downgraded once

246 each for imprecision and publication bias). GRADE assessment of certainty of evidence on effects of 247 increasing LCn3 on IBD and inflammatory outcomes are detailed in Additional Table 2. Six trials 
248 provided data on relapse in CD, four in UC. Meta-analysis suggests reduction in relapse rates of IBD 249 in those taking more $\mathrm{LCn} 3$ (RR $0.85,95 \%$ CI 0.72 to $1.01, \mathrm{I}^{2} 30 \%, 521$ relapses in 1196 participants, 250 Figure 1), and this was maintained (and statistically significant) in fixed effects analysis, when 251 retaining only trials at low summary risk of bias, trials at low risk from compliance problems and in 252 larger trials (see Additional Table 3). The funnel plot suggests that some small studies with increased 253 rates of relapse in the intervention group may be missing (Additional Figure 2), but similarity in effect 254 of fixed and random effects meta-analyses indicates this was not important. Data were mainly from 255 CD trials, and subgrouping suggested there was no statistically significant difference in effect between $256 \mathrm{CD}$ and UC subgroups (Figure 1). There were no differences in effect when subgrouping by 257 intervention type (though most studies were of supplementary capsules), dose, duration, age, sex, 258 medications taken or baseline IBD status, but there was a greater effect in the subgroup where LCn3 259 replaced saturated fats than other replacements ( $\mathrm{p}=0.02$, Additional Table 3 ).

Increasing LCn3 may reduce the risk of IBD worsening (low quality evidence, downgraded 261 once for risk of bias, once for imprecision). Two trials provided data on risk of worsening of CD, none 262 on UC. This limited data set suggested that LCn3 reduced risk of worsening CD (RR 0.85, 95\% CI 2630.71 to $1.03, \mathrm{I}^{2} 0 \%, 271$ participants disease worsened in 748 participants [54]). This did not alter with 264 fixed effects analysis, but neither study was at low summary risk of bias, or at low risk of compliance 265 problems (Additional Table 4). The effect of increasing LCn3 on IBD severity was unclear as the 266 evidence was of very low quality (downgraded once for risk of bias, twice for imprecision). Data on 267 disease severity were more limited than those for worsening, and included UC severity score, stool 268 frequency, stool consistency and rectal bleeding (one trial each of 18 or 20 participants, only stool 269 consistency included SDs to enable use in meta-analysis or assessment of statistical significance, 270 Figure $2[48,56])$. Neither study was at low summary risk of bias.

272 Effects of LCn3 on IBD diagnoses 
274 (downgraded twice for imprecision). We found limited data on diagnoses of colitis in two large trials 275 (RR 1.10, 95\% CI 0.63 to $1.92, \mathrm{I}^{2} 0 \%, 49$ diagnoses in 16,015 participants, Figure 3 [36, 39]). The 276 suggestion of increased risk in those taking LCn3 did not alter with fixed effects analysis, limiting to 277 trials at low summary risk of bias, low risk of compliance problems, or study size (Additional Table 278 5).

\section{Effects of LCn3 on inflammatory biomarkers in people with and without IBD}

Higher levels of inflammatory biomarkers equate to more inflammation. The effect of 282 increasing LCn3 on CRP was unclear as the evidence was of very low quality (downgraded once each 283 for inconsistency, imprecision and publication bias). Thirty-nine trials assessed effects of LCn3 on 284 CRP over at least 6 months, thirteen reporting CRP, twenty-six high sensitivity CRP (hs-CRP), but only 26 provided enough data to be included in meta-analysis. No included studies specifically recruited people with IBD at baseline. As there were not statistically significant differences between 287 CRP and hs-CRP subgroups, we pooled the results of both in all analyses. Baseline CRP ranged from $288<1$ to under $10 \mathrm{mg} / \mathrm{L}$ with a single trial having a baseline of $18 \mathrm{mg} / \mathrm{L}$ [57]. As the data were very 289 different in different trials we assumed this reflected differing analysis methods so ran the analyses 290 using standardised mean difference (SMD). This suggested little or no effect of increasing LCn3 on 291 CRP (SMD $-0.09,95 \%$ CI -0.21 to $0.03, \mathrm{I}^{2} 68 \%$, in 15,278 participants, Figure 4 ). Translating this 292 back into $\mathrm{mg} / \mathrm{L}$ using the AlphaOmega trial (the trial taking most weight in the meta-analysis [58]) 293 suggested a less than $10 \%$ fall in CRP with LCn3. This lack of effect did not alter in sensitivity 294 analyses by summary risk of bias, compliance or study size, but fixed effects analysis suggested a 295 clinically insignificant but statistically significant effect (SMD $-0.06,95 \%$ CI -0.12 to $-0.01, \mathrm{I}^{2} 68 \%$, 296 in 15,278 participants, Additional Table 6). The funnel plot suggested that some studies with lower 297 CRP in the LCn3 arm may be missing, if these studies were added back they would suggest a greater 
reduction by LCn3 of CRP (Additional Figure 3). There were no important differences between subgroups by intervention type, dose, duration, replacement, age, sex, medication used or baseline disease status (Figure $5 \&$ Additional Table 6).

Moderate quality evidence suggests that increasing LCn3 probably reduces ESR (downgraded once for imprecision). Seven trials assessed effects on ESR in the long-term, of which 6 were combined using SMD, suggesting a statistically significant reduction in those taking more LCn3 (SMD -0.23, 95\% CI -0.44 to $-0.01, \mathrm{I}^{2} 0 \%$, in 368 participants, Additional Table 7). The effect remained statistically significant in fixed effects analysis and limiting to trials at low summary risk of bias (MD $14.00 \mathrm{~mm} /$ hour, $95 \%$ CI -25.33 to $-2.67,1$ trial [37]) but the statistical significance was lost when with higher LCn3 intake (MD -14.0mm/hour, 95\% CI -25.3 to -2.7)[37]. No funnel plot, further sensitivity analyses or subgrouping was carried out as there were so few trials. As there was no difference in effect size whether random or fixed-effects analyses were carried out there was unlikely to be important small study bias.

The effect of increasing LCn3 on IL-6 was unclear as the evidence was of very low quality

315 (downgraded once each for risk of bias, inconsistency and imprecision). Twenty-two trials assessed 316 effects on IL-6 over at least 6 months, of which 18 were combined using SMD in random effects meta317 analysis (SMD $-0.35,95 \%$ CI -0.62 to $-0.07, \mathrm{I}^{2} 83 \%$, in 2234 participants, Figure 6 ). The suggestion 318 of reduction in IL-6 was highly heterogeneous, and the funnel plot was not interpretable (Additional 319 Figure 4), but effects using fixed and random-effects analyses were very similar so small study bias is 320 unlikely. The statistically significant reduction in IL-6 in those with higher LCn3 intake was also seen 321 in the sensitivity analyses using fixed effects and studies at low risk from compliance problems, but 322 statistical significance was lost when analyses were limited to trials at low summary risk of bias and 
323 larger trials (Additional Table 8). There was no clinically or statistically significant effect in the single

324 trial in people with existing IBD (32 participants with UC, MD 0.07pg/ml, 95\% CI -0.15 to 0.29)[46].

325 There were no differences between subgroups for intervention type, LCn3 dose, duration, replacement, 326 age or baseline health conditions, but there was a suggestion of greater effects in men. There were 327 also suggestions of different effects in different age groups, but there were no clear progressions so 328 this was probably spurious.

Increasing LCn3 may increase faecal calprotectin (low quality evidence, downgraded twice for

330 imprecision). One trial reported faecal calprotectin, in only 34 participants with UC at baseline, 331 suggesting a non-statistically significant increase with higher LCn3 (MD $16.1 \mu \mathrm{g} / \mathrm{g}$, 95\% CI -37.6 to $33269.8,34$ participants[46]). This single trial was at low summary risk of bias and low risk from 333 compliance problems.

334 Effects of LCn3 on TNF- $\alpha$, ICAM-1 and VCAM-1 were collated as secondary outcomes (Table 335 3, Additional Table 9), and GRADE was not assessed. None of the trials in people with existing IBD 336 reported any of these markers. Eighteen trials reported effects of LCn3 on TNF- $\alpha$ in pg/ml, of which 33714 could be included in meta-analysis. The forest plot suggested that LCn3 reduced TNF- $\alpha$ (SMD $3380.45,95 \%$ CI -0.81 to $-0.09, \mathrm{I}^{2} 86 \%, 1774$ participants, Additional Figure 5), but none of these trials 339 were at low summary risk of bias and the funnel plot was not interpretable (Additional Figure 6). Five 340 trials reported ICAM-1 in $\mathrm{ng} / \mathrm{ml}$ of which three could be included in meta-analysis, suggesting no 341 effect of LCn3 on ICAM-1 in the longer term (SMD 0.04, 95\% CI -0.43 to $0.50, \mathrm{I}^{2} 74 \%, 639$ 342 participants, not shown). Meta-analysis of the three of four trials reporting effects of LCn3 on VCAM3431 suggested no effect (SMD - $0.18,95 \%$ CI -0.87 to $0.51, \mathrm{I}^{2} 88 \%, 388$ participants, Additional Table $3449)$. 
Medication use was rarely reported, but one trial provided data on percentage of baseline non-

348 steroidal anti-inflammatory drug (NSAID) use, suggesting that NSAID use was lower with higher 349 LCn3 (MD $-43.5 \%, 95 \%$ CI -71.4 to $-15.6,64$ participants [59]). This single trial was not at low 350 summary risk of bias. Similarly, a single trial reported quality of life, assessed using the Health Activity 351 questionnaire (HAQ), suggesting similar levels of quality of life with higher and lower LCn3 intake 352 (MD $-0.02,95 \%$ CI -0.12 to $0.08,130$ participants, the trial was not at low summary risk of bias [60]). 353 Details of effects of LCn3 on measures of adiposity are systematically reviewed (as primary outcomes) 354 in a sister review, so not discussed here [18].

Effects of ALA

The GRADE table on effects of increasing ALA on primary outcomes is Additional Table 10.

358 We found no data on effects of increasing ALA on people with IBD on remission or relapse, severity, 359 worsening, or medication use, on inflammatory markers, or in diagnosis of IBD in people without IBD 360 at baseline. Four trials (in people without existing IBD but with CVD risk factors) assessed effects of 361 increasing ALA intake (up to $2 \mathrm{~g} /$ day) for 12 to 40 months on CRP. Baseline CRP was 1.8 to $4.9 \mathrm{mg} / \mathrm{L}$ 362 (mean $3.8 \mathrm{mg} / \mathrm{L}$ ). Meta-analysis and GRADE suggested high quality evidence of little or no effect 363 (SMD -0.00, 95\% CI -0.08 to 0.07, $\mathrm{I}^{2} 0 \%, 2715$ participants, Additional Figure 7, MD -0.00mg/L, 95\% 364 CI -0.16 to $0.16, \mathrm{I}^{2} 0 \%$ ). This did not alter in fixed effects analysis, limiting to the three trials at low 365 summary risk of bias, or at low risk of compliance problems (Additional Table 11). Two of the three 366 trials assessing effects of ALA on IL-6 were included in meta-analysis, suggesting low quality 367 evidence of little or no effect (SMD $-0.04,95 \%$ CI -0.33 to $0.24, \mathrm{I}^{2} 0 \%, 186$ participants, neither trial 368 at low summary risk of bias, Additional Figure $8, \mathrm{MD}-0.28 \mathrm{pg} / \mathrm{ml}, 95 \%$ CI -1.09 to $0.53, \mathrm{I}^{2} 0 \%$, quality 369 of evidence downgraded for once for imprecision, once for risk of bias). Effects did not differ by fixed 370 or random-effects analysis, Additional Table 12. Two trials reported on TNF- $\alpha$, suggesting little effect 371 of increasing ALA (SMD -0.18, 95\% CI -0.51 to 0.14, $\mathrm{I}^{2} 0 \%, 146$ participants, Additional Figure 9), 
372 which did not differ in the single trial at low summary risk of bias. No trials reported on effects of

373 ALA on ESR, faecal calprotectin, ICAM-1 or VCAM-1 or other secondary outcomes.

\section{Effects of omega-6}

The GRADE table for omega-6 is Additional Table 13. We found no data on effects of increasing omega-6 on people with IBD on worsening or medication use, or inflammatory markers, or in diagnosis of IBD in people without IBD at baseline. The effects of increasing omega-6 on IBD relapse and severity were unclear as the evidence for both were of very low quality. Limited information was provided on relapse ( 2 of 20 people with UC relapsed, RR 0.54, 95\% CI 0.04 to 7.36 ) and severity by a single trial of 20 people, providing data suggesting slightly greater but nonstatistically significant stool solidity (MD $-0.30,95 \%$ CI -0.73 to 0.13 , on a scale of 0 to 2 , with 0 being solid and 2 watery, 20 participants [48]). Data from the same study on stool frequency and rectal bleeding did not include measures of variance, so statistical significance was not clear.

(downgraded once each for risk of bias and imprecision). Meta-analysis of two of three trials assessing effects of omega-6 on CRP suggested little or no effect (SMD 0.09, 95\% CI -0.17 to 0.35, I' 0\%, 228 participants, MD $0.19 \mathrm{mg} / \mathrm{L}, 95 \% \mathrm{CI}-0.28$ to 0.66 , neither trial was at low summary risk of bias, the third trial provided no data on variance. Effects did not differ when using fixed instead of randomeffects meta-analysis, Additional Table 14. The effect of increasing omega-6 on ESR is unclear as the evidence is of very low quality (downgraded once for risk of bias, twice for imprecision). One of three trials assessing effects of omega-6 on ESR provided a measure of variance suggesting no effect (MD 4.00mm/hour, $95 \% \mathrm{CI}-10.55$ to $18.55,75$ participants without baseline IBD, not at low summary risk of bias, Additional Table 15). We found no studies assessing effects of omega-6 on IL-6, faecal calprotectin, ICAM-1, VCAM-1 or other secondary outcomes. A single trial assessed effects of omega- 6 on TNF- $\alpha$ (MD -0.40, 95\% CI -0.95 to $0.15,38$ participants, not at low summary risk of bias). 


\section{Effects of total PUFA}

We found no studies assessing effects of total PUFA on IBD relapse, worsening, severity, 400 medication use or inflammatory markers in people with IBD or on IBD diagnosis in people without 401 IBD at baseline, see GRADE table, Additional Table 16. Long-term effects of increasing total PUFA 402 on CRP are unclear as the evidence is of very low quality. Three of five trials assessing effects of 403 increasing total PUFA intake (up to $27.6 \mathrm{~g}$ /day for a duration of 6 to 56 months) on CRP could be 404 included in meta-analysis, suggesting no effect of total PUFA on CRP (SMD 0.25, 95\% CI -0.10 to $4050.60, \mathrm{I}^{2} 50 \%, 385$ participants, Figure 7, Additional Table 17). The single trial assessing ESR did not 406 provide any measure of variance. Increasing total PUFA may have little or no effect on IL-6, low 407 quality evidence (downgraded once each for risk of bias and imprecision). Two trials reporting effects 408 of total PUFA on IL-6 suggested no effect (SMD -0.09, 95\% CI -0.24 to 0.07, $\mathrm{I}^{2} 0 \%, 611$ participants 409 without IBD, neither trial was at low summary risk of bias, MD $-0.08 \mathrm{pg} / \mathrm{ml}, 95 \%$ CI -0.18 to 0.02 , 410 Figure 6, Additional Table 18). No trials assessed effects of total PUFA on faecal calprotectin or 411 secondary outcomes. 


\section{Discussion}

This is the most comprehensive meta-analysis of RCTs investigating long-term effects of

416 omega-3, omega-6 and total PUFA on treatment and prevention of IBD and on inflammatory markers

417 in people with and without IBD at baseline. We systematically reviewed the effects of omega-3,

418 omega-6 and total PUFA on IBD outcomes, including 83 RCTs (41,751 participants), of which 13

419 recruited people with IBD and 11 were at low summary risk of bias. Low quality evidence suggested

420 increasing LCn3 may reduce the risk of IBD relapse and worsening, and reduce ESR, but increase the

421 risk of IBD diagnosis and increase faecal calprotectin. Only one included trial (of LCn3) assessed

422 effects on faecal calprotectin, limiting our ability to draw conclusions on the effect of omega-3, omega-

4236 and PUFAs on this important biomarker. Evidence on effects of increasing ALA, omega-6 and total

424 PUFA were sparse, but increasing ALA has little or no effect on CRP and may have little effect on IL-

425 6. Increasing omega-6 may have little or no effect on CRP and increasing total PUFA may have little 426 or no effect on IL-6. Evidence for other primary outcomes was of very low quality or absent. Data on 427 inflammatory markers was often not useable in meta-analysis due to missing variance data or not being 428 reported numerically despite being measured, so there is considerable inherent risk of small study bias. 429 Evidence for effects of PUFA on inflammatory markers in people with existing IBD is very limited.

We were interested in how effects varied by UC and CD, intervention type, baseline severity, dose, duration and nutrients displaced by increased PUFA. For trials with participants with existing 432 IBD, the duration of intervention ranged from 6 to 24 months, and LCn3 doses were from 1.12 to 4.5 $433 \mathrm{~g} \mathrm{EPA/day} \mathrm{plus} 0.73$ to $2.4 \mathrm{~g}$ DHA/day. Where there were enough data to subgroup effects rarely 434 varied according to these variables, which may be due to limited data or to lack of effect of these 435 variables.

Our findings on effects of increasing LCn3 appear contradictory, suggesting reduction in IBD 
438 review of observational studies reflects this dissonance suggesting significant negative correlations 439 between fish consumption and CD incidence, and between LCn3 intake and UC risk, but no 440 associations between total dietary omega-3 or ALA intake and IBD incidence [61]. The Nurses' Health 441 Study suggested that energy-adjusted intake of omega- 6 or omega-3 was not associated with risk of 442 UC or CD but there was a (non-statistically significant) suggestion of a negative association between 443 LCn3 intake and UC risk [62]. On the other hand, a systematic review of trials found that LCn3 444 supplements were probably ineffective for maintaining remission in CD [63]. Despite strong 445 theoretical mechanisms for utility of LCn3 and negative effects of omega-6 on IBD and the 446 inflammatory process [8], current evidence is contradictory. The trials included in this systematic 447 review assessed effects of increasing LCn3 primarily through consumption of fish oil supplements. A 448 diet high in oily fish would increase LCn3 intake, but also iodine, protein, selenium etc so may have 449 different effects. Overall, this lack of clarity is reflected in the lack of guidelines on LCn3 450 supplementation in IBD management [5, 64-68], though the European Society of Parenteral and 451 Enteral Nutrition (ESPEN) specifically advises that a diet high in LCn3 and low in omega-6 is 452 preventative of IBD (based on individual observational studies), but against LCn3 supplementation for 453 maintenance of remission [69].

As we were interested in the mechanism of any effects of PUFAs via inflammatory processes on IBD, we took the novel step of also assessing effects of omega-3, omega-6 or PUFAs on 456 inflammatory biomarkers. Clear effects on inflammatory biomarkers could support assertions of anti457 or pro-inflammatory mechanisms of action and support effects on IBD outcomes. To underpin effects 458 on IBD we would expect to find that increasing LCn3 and ALA would reduce CRP, ESR, IL-6 and 459 faecal calprotectin, while increasing omega-6 and total PUFA (including all omega-3 and omega-6 460 fatty acids) would increase these markers. These effects were not seen in our included long-term trials, 461 except that increasing LCn3 appears to reduce ESR (in people with and without IBD) but increases 
462 faecal calprotectin, a specific marker for IBD, in people with IBD. This provides little or no evidence 463 to support pro- or anti-inflammatory effects of increasing LCn3, ALA, omega-6 or total PUFA intakes.

Despite measurement in 39 trials the evidence of long-term effects of LCn3 on CRP was of 465 very low quality, so effects were unclear, highlighting a need for standardisation of measurement (CRP 466 vs hs-CRP) and reporting. As CRP and ESR are identified as having a role in monitoring disease 467 activity and response to treatment [5, 64, 67], and correlate with IBD diagnosis [70], their lack of 468 response to omega-3 or omega- 6 fats in this review undermines the effect of omega- 3 and omega- 6 469 fats both on inflammation and on IBD. As faecal calprotectin is a specific and sensitive inflammatory 470 biomarker for IBD diagnosis, progression and severity [5, 64, 65, 70, 71] effects of omega-3 and 471 omega-6 on faecal calprotectin are particularly important. However, only one included trial (of LCn3) 472 assessed effects on faecal calprotectin, limiting our ability to draw conclusions on the effect of omega473 3, omega-6 and PUFAs on this important biomarker.

Most included studies measured IBD diagnosis, severity or progression or inflammatory 475 biomarkers. Measuring medication use and quality of life in people with IBD are equally as important 476 in measuring the impact of IBD on patients, and identifying and measuring outcomes that are important 477 to patients is the gold standard of high quality clinical research [72]. However, these outcomes were 478 rarely measured or reported, suggesting that this message has not been adequately received by those 479 conducting IBD research, and supporting the need for a core outcome set in IBD research that captures 480 clinically relevant and patient-centred metrics [73]. 


\section{Conclusion}

483

Despite rigorous searching for relevant trials, data are sparse on long-term effects of ALA, 484 omega-6 and total PUFA on clinical outcomes in IBD, prevention of IBD, and on inflammatory 485 markers in people with and without IBD. Methodologically only 11 of 83 included trials were at low 486 summary risk of bias, none of the seven trials in people with existing UC, and two of the six trials of 487 people with existing CD. Future trials of effects of fatty acids on IBD, and on inflammatory markers, 488 need to be of high methodological quality, using strong randomisation, allocation concealment, 489 masking of participants and outcome assessors, so that results are less susceptible to inherent bias. As 490 effects of LCn3 on IBD outcomes are contradictory, interpretation of results is difficult. Currently, 491 combined findings from clinical and biomarker outcomes suggest little or no effect of LCn3 on IBD 492 or inflammation.

There is a pressing need for high quality, well designed research using a core outcome set to 494 assess effects of interventions, particularly effects of increasing omega- 3 and omega- 6 fats, on IBD 495 diagnosis, progression, inflammatory biomarkers (particularly faecal calprotectin), medication use, 496 and quality of life. Additionally, existing trials of omega-3 and omega-6 interventions would ideally 497 report IBD diagnoses to allow assessment of preventive effects. 
Table 1. Brief characteristics of the 13 trials that assessed effects of PUFA on people with existing

\begin{tabular}{|c|c|c|c|}
\hline $\begin{array}{l}\text { Study name \& } \\
\text { references }\end{array}$ & Participants & $\begin{array}{l}\text { Intervention \& comparison, } \\
\text { duration, dose }\end{array}$ & $\begin{array}{l}\text { Summary } \\
\text { risk of bias }\end{array}$ \\
\hline $\begin{array}{l}\text { Almallah } 1998 \\
{[47,56]}\end{array}$ & $\begin{array}{l}\text { Individuals with ulcerative } \\
\text { colitis with only distal disease } \\
\text { (Europe) }\end{array}$ & $\begin{array}{l}\mathrm{n} 3 \mathrm{EPA}+\mathrm{DHA} \text { vs n6 LA, } 6 \\
\text { months, } 3.2 \mathrm{~g} / \mathrm{d} \mathrm{EPA}+2.4 \mathrm{~g} / \mathrm{d} \\
\text { DHA }\end{array}$ & $\begin{array}{l}\text { Moderate to } \\
\text { high }\end{array}$ \\
\hline $\begin{array}{l}\text { Belluzzi } 1996 \\
\text { [37] }\end{array}$ & $\begin{array}{l}\text { Individuals with established } \\
\text { diagnosis of CD in clinical } \\
\text { remission (Europe) }\end{array}$ & $\begin{array}{l}\text { n3 EPA+DHA vs mixed fat, } 12 \\
\text { months, } 1.8 \mathrm{~g} / \mathrm{d} \text { EPA }+0.9 \mathrm{~g} / \mathrm{d} \\
\text { DHA }\end{array}$ & Low \\
\hline $\begin{array}{l}\text { Belluzzi } 1997 \\
\text { [53] }\end{array}$ & $\begin{array}{l}\text { Individuals with CD in } \\
\text { remission } 1 \text { month after ileal } \\
\text { resection (Europe) }\end{array}$ & $\begin{array}{l}\text { n3 EPA+DHA vs mixed fat), } 12 \\
\text { months, } 1.8 \mathrm{~g} / \mathrm{d} \text { EPA }+0.9 \mathrm{~g} / \mathrm{d} \\
\text { DHA }\end{array}$ & $\begin{array}{l}\text { Moderate to } \\
\text { high }\end{array}$ \\
\hline $\begin{array}{l}\text { EPIC-1 } 2008 \\
{[54]}\end{array}$ & $\begin{array}{l}\text { Adults with quiescent CD and } \\
\text { CDAI score }<150 \text { (Europe, } \\
\text { North America \& Asia) }\end{array}$ & $\begin{array}{l}\text { n3 EPA vs mixed fats, } 52 \text { weeks, } \\
2.2 \mathrm{~g} / \mathrm{d} \text { EPA }+0.8 \mathrm{~g} / \mathrm{d} \text { DHA }\end{array}$ & $\begin{array}{l}\text { Moderate or } \\
\text { high }\end{array}$ \\
\hline $\begin{array}{l}\text { EPIC-2 } 2008 \\
{[54]}\end{array}$ & $\begin{array}{l}\text { Adults with a confirmed CD } \\
\text { and CDAI score }<150 \text { and } \\
\text { responding to steroid induction } \\
\text { therapy (Europe, North } \\
\text { America \& Asia) }\end{array}$ & $\begin{array}{l}\text { n3 EPA+DHA vs mixed fats, } 58 \\
\text { weeks, } 2.2 \mathrm{~g} / \mathrm{d} \text { EPA, } 0.8 \mathrm{~g} / \mathrm{d} \text { DHA }\end{array}$ & $\begin{array}{l}\text { Moderate or } \\
\text { high }\end{array}$ \\
\hline $\begin{array}{l}\text { FISHGASTRO - } \\
\text { Pot } 2009[46, \\
74,75]\end{array}$ & $\begin{array}{l}\text { Adults with colorectal polyps, } \\
\text { inactive UC or no macroscopic } \\
\text { signs of disease, given } \\
\text { colonoscopy (Europe) }\end{array}$ & $\begin{array}{l}\text { high } \mathrm{n} 3 \text { fish diet vs low } \mathrm{n} 3 \text { fish } \\
\text { diet vs low fish diet, } 6 \text { months, } \\
1.4 \mathrm{~g} / \mathrm{d} \text { or } 0.26 \mathrm{~g} / \mathrm{d} \text { EPA+DHA }\end{array}$ & $\begin{array}{l}\text { Moderate to } \\
\text { high }\end{array}$ \\
\hline $\begin{array}{l}\text { Greenfield } 1993 \\
{[48]}\end{array}$ & $\begin{array}{l}\text { People with stable UC for }>1 \\
\text { year and on }<10 \mathrm{mg} \\
\text { prednisolone/day (Europe) }\end{array}$ & $\begin{array}{l}\text { n3 EPA vs n6 GLA vs MUFA, } 6 \\
\text { months, } 1.12 \mathrm{~g} / \mathrm{d} \text { EPA \& } 0.73 \mathrm{~g} / \mathrm{d} \\
\text { DHA }\end{array}$ & $\begin{array}{l}\text { Moderate to } \\
\text { high }\end{array}$ \\
\hline $\begin{array}{l}\text { Hawthorne } 1992 \\
\text { [49] }\end{array}$ & $\begin{array}{l}\text { People with established UC } \\
\text { with } \geq 2 \text { relapses in past } 3 \text { years } \\
\text { (Europe) }\end{array}$ & $\begin{array}{l}\text { n3 EPA vs MUFA, } 12 \text { months, } \\
4.5 \mathrm{~g} / \mathrm{d} \mathrm{EPA}+1.08 \mathrm{~g} / \mathrm{d} \text { DHA }\end{array}$ & $\begin{array}{l}\text { Moderate or } \\
\text { high }\end{array}$ \\
\hline $\begin{array}{l}\text { Loeschke } 1996 \\
{[50]}\end{array}$ & $\begin{array}{l}\text { People with UC in remission } \\
\text { (Europe) }\end{array}$ & $\begin{array}{l}\text { n3 EPA+DHA vs n6 LA, } 24 \\
\text { months, 5.1g/d EPA+DHA }\end{array}$ & $\begin{array}{l}\text { Moderate or } \\
\text { high }\end{array}$ \\
\hline $\begin{array}{l}\text { Lorenz-Meyer } \\
1996 \text { [42] }\end{array}$ & $\begin{array}{l}\text { People with CD in remission } \\
\text { (but with a recent relapse) } \\
\text { (Europe) }\end{array}$ & $\begin{array}{l}\mathrm{n} 3 \text { EPA+DHA vs n6 LA, } 12 \\
\text { months, } 3.3 \mathrm{~g} / \mathrm{d} \text { EPA }+1.8 \mathrm{~g} / \mathrm{d} \\
\text { DHA }\end{array}$ & Low \\
\hline $\begin{array}{l}\text { Mantzaris } 1996 \\
\text { [51] }\end{array}$ & $\begin{array}{l}\text { People with UC in clinical, } \\
\text { endoscopic \& histological } \\
\text { remission (Europe) }\end{array}$ & $\begin{array}{l}\text { n3 EPA+DHA Vs MUFA, } 12 \\
\text { months, } 3.2 \mathrm{~g} / \mathrm{d} \text { EPA \& } 2.1 \mathrm{~g} / \mathrm{d} \\
\text { DHA }\end{array}$ & $\begin{array}{l}\text { Moderate to } \\
\text { high }\end{array}$ \\
\hline Mate 1991 [55] & $\begin{array}{l}\text { People with CD in remission } \\
\text { (Europe) }\end{array}$ & $\begin{array}{l}\text { n3 EPA+DHA vs nil, } 24 \text { months, } \\
\text { dose unclear }\end{array}$ & $\begin{array}{l}\text { Moderate or } \\
\text { high }\end{array}$ \\
\hline $\begin{array}{l}\text { Varghese } 2000 \\
\text { [52] }\end{array}$ & $\begin{array}{l}\text { People with active extensive } \\
\text { UC (Europe) }\end{array}$ & $\begin{array}{l}\text { n3 vs n6, } 6 \text { months, } 5.6 \mathrm{mg} / \mathrm{d} \text { (sic) } \\
\text { n3 (unclear whether ALA or } \\
\text { LCn3) }\end{array}$ & $\begin{array}{l}\text { Moderate to } \\
\text { high }\end{array}$ \\
\hline
\end{tabular}

\section{Footnotes}

$505 \quad$ ALA $=$ alpha-linolenic acid

$506 \mathrm{CD}=$ Crohn's disease 
$507 \quad \mathrm{CDAI}=$ Crohn's disease activity index

$508 \quad$ DHA $=$ docosahexaenoic acid

509 EPA $=$ eicosapentaenoic acid or icosapentaenoic acid

510 GLA = gamma linolenic acid

$511 \quad$ LA $=$ linoleic acid

512 LCn3 = long-chain omega 3

513 MUFA = mono-unsaturated fatty acids

514 n3 = omega 3

515 n6 $=$ omega 6

$516 \quad$ UC $=$ Ulcerative colitis

517

518 
519 Table 2. Characteristics of included studies with data on prevention of IBD, including risk of bias 520 and references

521

\begin{tabular}{|l|l|l|l|}
\hline $\begin{array}{l}\text { Study name \& } \\
\text { references }\end{array}$ & Participants & $\begin{array}{l}\text { Intervention \& comparison, duration, } \\
\text { dose }\end{array}$ & $\begin{array}{l}\text { Summary } \\
\text { risk of bias }\end{array}$ \\
\hline $\begin{array}{l}\text { ASCEND 2012 } \\
{[36,76]}\end{array}$ & People with DM, without & n-3 EPA + DHA vs MUFA, median 7.4 & Low \\
\hline $\begin{array}{l}\text { DREAM Asbell } \\
\text { 2018 }[39,77]\end{array}$ & Adults with dry eye & $\begin{array}{l}\text { Lears, 460mg/d EPA + 380mg/d DHA } \\
1 \mathrm{~g} \text { DHA/d }\end{array}$ & Low \\
\hline
\end{tabular}

\section{Footnotes}

DHA = docosahexaenoic acid

$\mathrm{DM}=$ diabetes mellitus

EPA $=$ eicosapentaenoic acid or icosapentaenoic acid 
532 Table 3. Characteristics of included studies reporting markers of inflammation, including risk of bias

\begin{tabular}{|c|c|c|c|}
\hline $\begin{array}{l}\text { Study name \& } \\
\text { references }\end{array}$ & Participants & $\begin{array}{l}\text { Intervention \& comparison, duration, } \\
\text { dose }\end{array}$ & $\begin{array}{l}\text { Summary } \\
\text { risk of bias }\end{array}$ \\
\hline $\begin{array}{l}\text { AFFORD } \\
2014[78,79]\end{array}$ & $\begin{array}{l}\text { People with symptomatic } \\
\text { paroxysmal or persistent AF }\end{array}$ & $\begin{array}{l}\text { n3 EPA+DHA vs n6, } 12 \text { months, } 1.6 \mathrm{~g} / \mathrm{d} \\
\text { EPA + 0.8g/d DHA }\end{array}$ & $\begin{array}{l}\text { Moderate } \\
\text { or high }\end{array}$ \\
\hline $\begin{array}{l}\text { AlphaOmega - } \\
\text { ALA }[35,80]\end{array}$ & $\begin{array}{l}60-80 \text { year olds with previous } \\
\text { MI }\end{array}$ & $\begin{array}{l}\text { n3 ALA vs MUFA, } 40 \text { months, ALA } \\
\text { 2g/d }\end{array}$ & Low \\
\hline $\begin{array}{l}\text { AlphaOmega - } \\
\text { EPA+DHA [35, } \\
80]\end{array}$ & $\begin{array}{l}\text { 60-80 year olds with previous } \\
\text { MI }\end{array}$ & $\begin{array}{l}\text { n3 EPA+DHA vs MUFA, } 40 \text { months, } \\
\text { EPA+DHA } 0.4 \mathrm{~g} / \mathrm{d}\end{array}$ & Low \\
\hline $\begin{array}{l}\text { Araujo } 2014 \\
{[81]}\end{array}$ & People with RA & $\begin{array}{l}\text { n3 vs unclear control, } 6 \text { months, dose } \\
\text { unclear }\end{array}$ & $\begin{array}{l}\text { Moderate } \\
\text { to high }\end{array}$ \\
\hline $\begin{array}{l}\text { Balfego } 2016 \\
\text { [82] }\end{array}$ & $\begin{array}{l}\text { Drug-naive patients with type } 2 \\
\text { DM }\end{array}$ & $\begin{array}{l}\text { n3 EPA+DHA vs mixed fats, } 6 \text { months, } \\
\text { dose unclear }\end{array}$ & $\begin{array}{l}\text { Moderate } \\
\text { or high }\end{array}$ \\
\hline Belch 1988 [83] & $\begin{array}{l}\text { People with classical or } \\
\text { definite RA }\end{array}$ & $\begin{array}{l}\text { n6 GLA vs n6 GLA + n3 EPA vs nil, } 12 \\
\text { months, EPA } 0.24 \mathrm{~g} / \mathrm{d}+\text { GLA } 0.45 \mathrm{~g} / \mathrm{d}\end{array}$ & $\begin{array}{l}\text { Moderate } \\
\text { to high }\end{array}$ \\
\hline $\begin{array}{l}\text { Belluzzi } 1996 \\
\text { [37] }\end{array}$ & $\begin{array}{l}\text { Individuals with established } \\
\text { diagnosis of CD in clinical } \\
\text { remission }\end{array}$ & $\begin{array}{l}\text { n3 EPA+DHA vs mixed fat, } 12 \text { months, } \\
1.8 \mathrm{~g} / \mathrm{d} \text { EPA }+0.9 \mathrm{~g} / \mathrm{d} \text { DHA }\end{array}$ & Low \\
\hline $\begin{array}{l}\text { Berbert } 2005 \\
{[57]}\end{array}$ & People with RA & $\begin{array}{l}\text { n3 EPA+DHA vs n6 LA, } 24 \text { weeks, } \\
1.8 \mathrm{~g} / \mathrm{d} \text { EPA \& } 1.2 \mathrm{~g} / \mathrm{d} \text { DHA }\end{array}$ & $\begin{array}{l}\text { Moderate } \\
\text { or high }\end{array}$ \\
\hline Bo 2017 [84] & $\begin{array}{l}\text { Older adults with mild } \\
\text { cognitive impairment }\end{array}$ & $\begin{array}{l}\text { n3 EPA+DHA vs MUFA), } 6 \text { months, } 480 \\
\text { mg/d DHA and } 720 \mathrm{mg} / \mathrm{d} \text { EPA }\end{array}$ & $\begin{array}{l}\text { Moderate } \\
\text { or high }\end{array}$ \\
\hline Brox 2001 [85] & $\begin{array}{l}\text { Subjects with moderate } \\
\text { hypercholesterolaemia }\end{array}$ & $\begin{array}{l}\text { n3 EPA+DHA from cod liver vs } \mathrm{n} 3 \\
\text { EPA+DHA from seal oil vs nil, } 14 \\
\text { months, seal oil } 1.1 \mathrm{~g} / \mathrm{d} \text { EPA }+1.5 / \mathrm{d} \\
\text { DHA, Cod liver oil } 1.5 \mathrm{~g} / \mathrm{d} \text { EPA }+1.8 \mathrm{~g} / \mathrm{d} \\
\text { DHA }\end{array}$ & $\begin{array}{l}\text { Moderate } \\
\text { or high }\end{array}$ \\
\hline $\begin{array}{l}\text { Brzeski } 1991 \\
{[86]}\end{array}$ & $\begin{array}{l}\text { People with rheumatoid } \\
\text { arthritis and upper GI lesions } \\
\text { due to NSAID intake }\end{array}$ & $\begin{array}{l}\text { n6 GLA vs MUFA), } 6 \text { months, } 0.54 \mathrm{~g} / \mathrm{d} \\
\text { GLA }\end{array}$ & $\begin{array}{l}\text { Moderate } \\
\text { to high }\end{array}$ \\
\hline Clark 2016 [38] & $\begin{array}{l}\text { Adults with impaired glucose } \\
\text { metabolism or type } 2 \text { diabetes } \\
\text { mellitus }\end{array}$ & $\begin{array}{l}\text { n3 EPA+DHA vs n6 LA, } 9 \text { months, } \\
\text { 3.9g/d EPA+DHA }\end{array}$ & Low \\
\hline $\begin{array}{l}\text { Darghosian } \\
2015 \text { [87] }\end{array}$ & $\begin{array}{l}\text { People with paroxysmal or } \\
\text { persistent AF }\end{array}$ & $\begin{array}{l}\text { n3 EPA+DHA vs n6 LA, } 6 \text { months, } \\
1.86 \mathrm{~g} / \mathrm{d} \text { EPA \& } 1.5 \mathrm{~g} / \mathrm{d} \text { DHA }\end{array}$ & $\begin{array}{l}\text { Moderate } \\
\text { or high }\end{array}$ \\
\hline $\begin{array}{l}\text { de Luis } 2016 \\
\text { [88] }\end{array}$ & $\begin{array}{l}\text { Generally healthy individuals } \\
\text { with obesity }\end{array}$ & $\begin{array}{l}\text { n3 DHA vs MUFA, } 6 \text { months, } 500 \mathrm{mg} / \mathrm{d} \\
\text { DHA then } 250 \mathrm{mg} / \mathrm{d}\end{array}$ & $\begin{array}{l}\text { Moderate } \\
\text { or high }\end{array}$ \\
\hline $\begin{array}{l}\text { Derosa } 2009 \\
{[89]}\end{array}$ & $\begin{array}{l}\text { Adults with combined } \\
\text { dyslipidaemia }\end{array}$ & $\begin{array}{l}\text { n3 EPA+DHA vs non-fat placebo, } 6 \\
\text { months, } 1.13 \mathrm{~g} / \mathrm{d} \text { EPA }+1.88 \mathrm{~g} / \mathrm{d} \text { DHA }\end{array}$ & $\begin{array}{l}\text { Moderate } \\
\text { or high }\end{array}$ \\
\hline $\begin{array}{l}\text { Derosa } 2011 \\
{[90]}\end{array}$ & $\begin{array}{l}\text { Adults with combined } \\
\text { lipidaemia }\end{array}$ & $\begin{array}{l}\text { n3 EPA+DHA vs non-fat placebo, } 6 \\
\text { months, } 1.2 \mathrm{~g} / \mathrm{d} \text { EPA + } 1.35 \mathrm{~g} / \mathrm{d} \text { DHA }\end{array}$ & $\begin{array}{l}\text { Moderate } \\
\text { or high }\end{array}$ \\
\hline $\begin{array}{l}\text { Deslypere } 1992 \\
{[91-93]}\end{array}$ & Healthy monks & $\begin{array}{l}\text { n3 EPA+DHA (3 different doses) vs } \\
\text { MUFA, } 12 \text { months, } 1.12 \mathrm{~g} / \mathrm{d} ; 2.24 \mathrm{~g} / \mathrm{d} \text { or } \\
\text { 3.37g/d EPA + DHA }\end{array}$ & $\begin{array}{l}\text { Moderate } \\
\text { or high }\end{array}$ \\
\hline $\begin{array}{l}\text { DO IT - Einvik } \\
2010 \text { [94-99] }\end{array}$ & $\begin{array}{l}\text { Elderly men with long standing } \\
\text { dyslipidaemia or hypertension }\end{array}$ & $\begin{array}{l}\text { n3 DHA+EPA vs n6 LA, } 36 \text { months, } \\
0.84 \mathrm{~g} / \mathrm{d} \text { EPA + } 0.48 \mathrm{~g} / \mathrm{d} \text { DHA }\end{array}$ & $\begin{array}{l}\text { Moderate } \\
\text { or high }\end{array}$ \\
\hline
\end{tabular}




\begin{tabular}{|c|c|c|c|}
\hline $\begin{array}{l}\text { Ebrahimi } 2009 \\
{[100]}\end{array}$ & $\begin{array}{l}\text { People with metabolic } \\
\text { syndrome }\end{array}$ & $\begin{array}{l}\text { n3 EPA+DHA vs nil, } 6 \text { months, } 180 \mathrm{mg} / \mathrm{d} \\
\text { EPA, } 120 \mathrm{mg} / \mathrm{d} \text { DHA }\end{array}$ & $\begin{array}{l}\text { Moderate } \\
\text { or high }\end{array}$ \\
\hline $\begin{array}{l}\text { ELIA - Takaki } \\
2011[101]\end{array}$ & $\begin{array}{l}\text { People with CAD and } \\
\text { dyslipidaemia on statins }\end{array}$ & n3 EPA vs nil, 11 months, $1.8 \mathrm{~g} / \mathrm{d}$ EPA & $\begin{array}{l}\text { Moderate } \\
\text { or high }\end{array}$ \\
\hline $\begin{array}{l}\text { ENRGISE } 2016 \\
{[102-104]}\end{array}$ & $\begin{array}{l}\text { People aged } 70+\text { years with } \\
\text { walking or stair-climbing } \\
\text { difficulty }\end{array}$ & $\begin{array}{l}\text { LCn-3 vs PUFA, } 12 \text { months, } 0.8 \mathrm{~g} / \mathrm{d} \text { EPA } \\
\text { plus } 0.4 \mathrm{~g} / \mathrm{d} \text { DHA }\end{array}$ & $\begin{array}{l}\text { Moderate } \\
\text { to high }\end{array}$ \\
\hline $\begin{array}{l}\text { EPE-A } 2014 \\
{[105]}\end{array}$ & $\begin{array}{l}\text { People with non-alcoholic } \\
\text { steatohepatitis (NASH) and } \\
\text { non-alcoholic fatty liver } \\
\text { disease (NAFLD) }\end{array}$ & $\begin{array}{l}\text { n3 EPA, low dose vs high dose vs } \\
\text { unclear placebo, } 12 \text { months, } 2.7 \mathrm{~g} / \mathrm{d} \text { or } \\
1.8 \mathrm{~g} / \mathrm{d} \text { EPA+DHA }\end{array}$ & $\begin{array}{l}\text { Moderate } \\
\text { or high }\end{array}$ \\
\hline $\begin{array}{l}\text { EPIC-1 } 2008 \\
{[54]}\end{array}$ & $\begin{array}{l}\text { Adults with quiescent CD and } \\
\text { CDAI score }<150\end{array}$ & $\begin{array}{l}\text { n3 EPA vs mixed fats, } 52 \text { weeks, } 2.2 \mathrm{~g} / \mathrm{d} \\
\text { EPA }+0.8 \mathrm{~g} / \mathrm{d} \text { DHA }\end{array}$ & $\begin{array}{l}\text { Moderate } \\
\text { or high }\end{array}$ \\
\hline $\begin{array}{l}\text { EPIC-2 } 2008 \\
{[54]}\end{array}$ & $\begin{array}{l}\text { Adults with a confirmed CD } \\
\text { and CDAI score }<150 \text { and } \\
\text { responding to steroid induction } \\
\text { therapy }\end{array}$ & $\begin{array}{l}\text { n3 EPA+DHA vs mixed fats, } 58 \text { weeks, } \\
2.2 \mathrm{~g} / \mathrm{d} \text { EPA, } 0.8 \mathrm{~g} / \mathrm{d} \text { DHA }\end{array}$ & $\begin{array}{l}\text { Moderate } \\
\text { or high }\end{array}$ \\
\hline $\begin{array}{l}\text { EPOCH } 2011 \\
{[40,106]}\end{array}$ & $\begin{array}{l}\text { Healthy older adults with no } \\
\text { cognitive impairment }\end{array}$ & $\begin{array}{l}\text { n3 EPA+DHA vs MUFA, } 18 \text { months, } \\
1.72 \mathrm{~g} / \mathrm{d} \text { DHA and } 0.60 \mathrm{~g} / \mathrm{d} \text { EPA }\end{array}$ & Low \\
\hline $\begin{array}{l}\text { Eschen } 2010 \\
\text { [107] }\end{array}$ & $\begin{array}{l}\text { People with chronic heart } \\
\text { failure }\end{array}$ & $\begin{array}{l}\text { n3 EPA+DHA vs MUFA, } 6 \text { months, } \\
0.9 \mathrm{~g} / \mathrm{d} \text { EPA+DHA }\end{array}$ & $\begin{array}{l}\text { Moderate } \\
\text { or high }\end{array}$ \\
\hline $\begin{array}{l}\text { Finnegan } 2003 \\
{[108,109]}\end{array}$ & People with hyperlipidaemia & $\begin{array}{l}\text { n3 EPA+DHA vs n3 ALA vs n6 LA, } 6 \\
\text { months, } 1.7 \mathrm{~g} / \mathrm{d} \text { or } 0.8 \mathrm{~g} / \mathrm{d} \text { EPA+DHA, } \\
9.5 \mathrm{~g} / \mathrm{d} \text { or } 4.5 \mathrm{~g} / \mathrm{d} \text { ALA }\end{array}$ & $\begin{array}{l}\text { Moderate } \\
\text { or high }\end{array}$ \\
\hline $\begin{array}{l}\text { FISHGASTRO - } \\
\text { Pot } 2009[46, \\
74,75]\end{array}$ & $\begin{array}{l}\text { Adults visiting the hospital for } \\
\text { colonoscopy with colorectal } \\
\text { polyps, inactive UC or no } \\
\text { macroscopic signs of disease }\end{array}$ & $\begin{array}{l}\text { high } \mathrm{n} 3 \text { fish diet vs low } \mathrm{n} 3 \text { fish diet vs } \\
\text { low fish diet, } 6 \text { months, } 1.4 \mathrm{~g} / \mathrm{d} \text { or } 0.26 \mathrm{~g} / \mathrm{d} \\
\text { EPA+DHA }\end{array}$ & $\begin{array}{l}\text { Moderate } \\
\text { to high }\end{array}$ \\
\hline $\begin{array}{l}\text { FLAX-PAD } \\
2013[41,110- \\
113]\end{array}$ & $\begin{array}{l}\text { People with peripheral artery } \\
\text { disease }\end{array}$ & $\begin{array}{l}\text { n3 ALA vs mixed fat, } 12 \text { months, unclear } \\
\text { ALA dose }\end{array}$ & Low \\
\hline $\begin{array}{l}\text { Kanorsky } 2007 \\
{[114]}\end{array}$ & $\begin{array}{l}\text { People with persistent atrial } \\
\text { fibrillation }\end{array}$ & $\begin{array}{l}\text { n3 vs nil, } 12 \text { months, dose and type } \\
\text { unclear }\end{array}$ & $\begin{array}{l}\text { Moderate } \\
\text { to high }\end{array}$ \\
\hline $\begin{array}{l}\text { Krebs } 2006 \\
{[115]}\end{array}$ & $\begin{array}{l}\text { Overweight hyperinsulinaemic } \\
\text { women }\end{array}$ & $\begin{array}{l}\text { n3 EPA+DHA vs n6 LA, } 6 \text { months, } 1.3 \mathrm{~g} \\
\text { EPA+ 2.9g DHA }\end{array}$ & $\begin{array}{l}\text { Moderate } \\
\text { or high }\end{array}$ \\
\hline $\begin{array}{l}\text { Kremer } 1995 \\
{[116]}\end{array}$ & $\begin{array}{l}\text { People with definite or classic } \\
\text { active RA }\end{array}$ & $\begin{array}{l}\text { n3 EPA+DHA vs n6 LA), } 6 \text { or } 7 \text { months, } \\
130 \mathrm{mg} / \mathrm{kg} / \mathrm{d} \text { EPA + DHA }\end{array}$ & $\begin{array}{l}\text { Moderate } \\
\text { or high }\end{array}$ \\
\hline $\begin{array}{l}\text { Kristensen } 2016 \\
{[117]}\end{array}$ & People with psoriatic arthritis & $\begin{array}{l}\text { LCn } 3 \text { vs MUFA, } 6 \text { months, } 1.5 \mathrm{~g} / \mathrm{d} \text { EPA, } \\
1.5 \mathrm{~g} / \mathrm{d} \text { DHA }\end{array}$ & $\begin{array}{l}\text { Moderate } \\
\text { to high }\end{array}$ \\
\hline $\begin{array}{l}\text { Kumar } 2008 \\
{[118]}\end{array}$ & People with RA & $\begin{array}{l}\text { n6 GLA vs MUFA, } 9 \text { months, } 1.32 \mathrm{~g} / \mathrm{d} \\
\text { GLA }\end{array}$ & $\begin{array}{l}\text { Moderate } \\
\text { to high }\end{array}$ \\
\hline Lalia 2015 [119] & Insulin resistant adults & $\begin{array}{l}\text { n3 EPA+DHA vs MUFA, } 6 \text { months, } \\
2.7 \mathrm{~g} / \mathrm{d} \text { EPA+ } 1.2 \mathrm{~g} / \mathrm{d} \text { DHA }\end{array}$ & $\begin{array}{l}\text { Moderate } \\
\text { or high }\end{array}$ \\
\hline Lau 1993 [59] & $\begin{array}{l}\text { People with definite or } \\
\text { classical RA requiring NSAIDs }\end{array}$ & $\begin{array}{l}\text { n3 EPA+DHA vs nil), } 12 \text { months, } 1.71 \mathrm{~g} \\
\text { EPA + } 1.14 \mathrm{~g} \text { DHA }\end{array}$ & $\begin{array}{l}\text { Moderate } \\
\text { to high }\end{array}$ \\
\hline $\begin{array}{l}\text { Leventhal } 1993 \\
{[120]}\end{array}$ & $\begin{array}{l}\text { People with RA and active } \\
\text { synovitis }\end{array}$ & $\begin{array}{l}\text { n6 GLA vs mixed fats including LA, } 24 \\
\text { weeks, } 1.4 \mathrm{~g} / \mathrm{d} \text { GLA }\end{array}$ & $\begin{array}{l}\text { Moderate } \\
\text { to high }\end{array}$ \\
\hline $\begin{array}{l}\text { Leventhal } 1994 \\
\text { [121] }\end{array}$ & $\begin{array}{l}\text { People with RA and active } \\
\text { synovitis }\end{array}$ & $\begin{array}{l}\text { n6 GLA \& n3 ALA vs n6 LA, } 24 \text { weeks, } \\
\text { 2g/d GLA }\end{array}$ & $\begin{array}{l}\text { Moderate } \\
\text { to high }\end{array}$ \\
\hline
\end{tabular}




\begin{tabular}{|c|c|c|c|}
\hline Li 2015 [122] & $\begin{array}{l}\text { People diagnosed with } \\
\text { pathological non-alcoholic } \\
\text { steatohepatitis (NASH) }\end{array}$ & $\begin{array}{l}\text { n3 EPA+DHA vs nil, } 6 \text { months, dose } \\
\text { unclear }\end{array}$ & $\begin{array}{l}\text { Moderate } \\
\text { or high }\end{array}$ \\
\hline $\begin{array}{l}\text { MARGARIN - } \\
\text { Bemelmans } \\
2002[43,123]\end{array}$ & $\begin{array}{l}\text { Hypercholesterolaemic adults } \\
\text { with } 2 \text { or more CVD risk } \\
\text { factors }\end{array}$ & n3 ALA vs n6 LA, 2 years, dose unclear & Low \\
\hline $\begin{array}{l}\text { MARINA - } \\
\text { Sanders } 2011 \\
{[44]}\end{array}$ & $\begin{array}{l}\text { Non-smoking men and women } \\
\text { aged } 45-70 y\end{array}$ & $\begin{array}{l}\text { n-3 EPA+DHA at three different doses } \\
\text { vs MUFA, } 12 \text { months, } 0.45 \mathrm{~g} / \mathrm{d} \text { or } 0.9 \mathrm{~g} / \mathrm{d} \\
\text { or } 1.8 \mathrm{~g} / \mathrm{d} \text { EPA+DHA }\end{array}$ & Low \\
\hline $\begin{array}{l}\text { Martinez } 2014 \\
{[124]}\end{array}$ & $\begin{array}{l}\text { People treated for chronic } \\
\text { periodontitis }\end{array}$ & $\begin{array}{l}\text { n3 EPA+DHA vs unclear, } 12 \text { months, } \\
0.18 \mathrm{~g} / \mathrm{d} \text { EPA, } 0.12 \mathrm{~g} / \mathrm{d} \text { DHA }\end{array}$ & $\begin{array}{l}\text { Moderate } \\
\text { or high }\end{array}$ \\
\hline Mate 1991 [55] & $\begin{array}{l}\text { People with Crohn's Disease in } \\
\text { remission }\end{array}$ & $\begin{array}{l}\text { n3 EPA+DHA vs nil, } 24 \text { months, dose } \\
\text { unclear }\end{array}$ & $\begin{array}{l}\text { Moderate } \\
\text { or high }\end{array}$ \\
\hline $\begin{array}{l}\text { MENU - Rock } \\
2016[125]\end{array}$ & $\begin{array}{l}\text { Overweight and obese women, } \\
\text { of whom half were insulin } \\
\text { resistant }\end{array}$ & n3 ALA vs nil, 12 months, dose unclear & $\begin{array}{l}\text { Moderate } \\
\text { or high }\end{array}$ \\
\hline $\begin{array}{l}\text { Moore } 2006 \\
{[126]}\end{array}$ & Overweight or obese adults & $\begin{array}{l}\text { high LCn3 \& high ALA vs high LCn3 \& } \\
\text { n6 vs low LCn3 \& high ALA vs low } \\
\text { LCn3 \& n6, also a control arm), } 6 \\
\text { months, } 0.1 \mathrm{~g} / \mathrm{d} \text { or } 0.65 \mathrm{~g} / \mathrm{d} \text { LCn } 3 \text {, ALA } \\
\text { doses unclear }\end{array}$ & $\begin{array}{l}\text { Moderate } \\
\text { to high }\end{array}$ \\
\hline $\begin{array}{l}\text { MUFFIN Miller } \\
2016 \text { [127] }\end{array}$ & $\begin{array}{l}\text { Middle-aged men and women } \\
\text { with metabolic syndrome }\end{array}$ & $\begin{array}{l}\text { PUFA \& n6 vs MUFA, } 6 \text { months, } \\
27.6 \mathrm{~g} / \mathrm{d} \text { PUFA }\end{array}$ & $\begin{array}{l}\text { Moderate } \\
\text { or high }\end{array}$ \\
\hline Niki 2016 [128] & $\begin{array}{l}\text { Patients with angina and } \\
\text { hypertension treated with } \\
\text { strong statins }\end{array}$ & $\begin{array}{l}\text { n3 EPA vs nil, } 6 \text { months, 1.8g/d EPA } \\
\text { ester }\end{array}$ & $\begin{array}{l}\text { Moderate } \\
\text { or high }\end{array}$ \\
\hline $\begin{array}{l}\text { Nishio } 2014 \\
\text { [129] }\end{array}$ & $\begin{array}{l}\text { People with untreated } \\
\text { dyslipidaemia and thin-cap } \\
\text { fibroatheroma }\end{array}$ & $\begin{array}{l}\text { n3 EPA vs nil, both with statin, } 9 \\
\text { months, } 1.8 \mathrm{~g} / \mathrm{d} \text { EPA }\end{array}$ & $\begin{array}{l}\text { Moderate } \\
\text { or high }\end{array}$ \\
\hline $\begin{array}{l}\text { Nodari } 2009 \\
{[130]}\end{array}$ & $\begin{array}{l}\text { People with cardiomyopathy } \\
\text { and frequent or repetitive } \\
\text { ventricular arrhythmia }\end{array}$ & $\begin{array}{l}\text { n3 EPA+DHA vs MUFA, } 6 \text { months, } \\
0.87 \mathrm{~g} / \mathrm{d} \text { EPA }+1.44 \mathrm{~g} / \mathrm{d} \text { DHA }\end{array}$ & $\begin{array}{l}\text { Moderate } \\
\text { or high }\end{array}$ \\
\hline $\begin{array}{l}\text { Nodari } 2011 \mathrm{HF} \\
{[131]}\end{array}$ & $\begin{array}{l}\text { People with heart failure (non- } \\
\text { ischaemic dilated } \\
\text { cardiomyopathy) }\end{array}$ & $\begin{array}{l}\text { n3 DHA+EPA vs MUFA, } 12 \text { months, } \\
1.7 \mathrm{~g} / \mathrm{d} \text { EPA+DHA at a ratio of } 0.9 \text { to } 1.5\end{array}$ & $\begin{array}{l}\text { Moderate } \\
\text { or high }\end{array}$ \\
\hline $\begin{array}{l}\text { Nogueira } 2016 \\
{[132]}\end{array}$ & $\begin{array}{l}\text { Patients with non-alcoholic } \\
\text { steatohepatitis }\end{array}$ & $\begin{array}{l}\text { n3 EPA+DHA vs non-fat, } 6 \text { months, } \\
0.6 \mathrm{~g} / \mathrm{d} \text { ALA }+0.194 \mathrm{~g} / \mathrm{d} \text { EPA }+0.15 \mathrm{~g} / \mathrm{d} \\
\text { DHA }\end{array}$ & $\begin{array}{l}\text { Moderate } \\
\text { or high }\end{array}$ \\
\hline $\begin{array}{l}\text { OFAMI - Nilsen } \\
2001[133]\end{array}$ & $\begin{array}{l}\text { Patients recruited } 4-8 \text { days } \\
\text { after confirmed MI }\end{array}$ & $\begin{array}{l}\text { n3 EPA+DHA vs n6 LA, } 2 \text { years, } 3.5 \mathrm{~g} / \mathrm{d} \\
\text { EPA+DHA }\end{array}$ & $\begin{array}{l}\text { Moderate } \\
\text { or high }\end{array}$ \\
\hline $\begin{array}{l}\text { OMEGA- } \\
\text { Remodel } 2016 \\
{[134-136]}\end{array}$ & People after acute MI & $\begin{array}{l}\text { n3 EPA+DHA vs n6 LA, } 6 \text { months, } \\
1.86 \mathrm{~g} / \mathrm{d} \text { EPA + } 1.5 \mathrm{~g} / \mathrm{d} \text { DHA }\end{array}$ & $\begin{array}{l}\text { Moderate } \\
\text { or high }\end{array}$ \\
\hline $\begin{array}{l}\text { OmegAD } 2008 \\
{[137-143]}\end{array}$ & $\begin{array}{l}\text { People with mild to moderate } \\
\text { Alzheimer's disease \& stable } \\
\text { comorbidities }\end{array}$ & $\begin{array}{l}\text { n3 EPA+DHA vs. n6 LA, } 6 \text { months, } \\
1.72 \mathrm{~g} / \mathrm{d} \text { DHA + } 600 \mathrm{mg} \text { EPA }\end{array}$ & $\begin{array}{l}\text { Moderate } \\
\text { or high }\end{array}$ \\
\hline ORL 2013 [144] & $\begin{array}{l}\text { Adults with } \\
\text { hypertriglyceridaemia }\end{array}$ & $\begin{array}{l}\text { n3 EPA+DHA high dose vs low dose vs } \\
\text { n3 EPA, } 12 \text { months, } 1.86 \mathrm{~g} / \mathrm{d} \text { EPA }+1.5\end{array}$ & $\begin{array}{l}\text { Moderate } \\
\text { or high }\end{array}$ \\
\hline
\end{tabular}




\begin{tabular}{|c|c|c|c|}
\hline & & $\begin{array}{l}\text { g/d DHA or } 0.93 \mathrm{~g} / \mathrm{d} E P A+0.75 \mathrm{~g} / \mathrm{d} \\
\text { DHA }\end{array}$ & \\
\hline $\begin{array}{l}\text { Patch 2005 } \\
{[145,146]}\end{array}$ & $\begin{array}{l}\text { Healthy overweight people } \\
\text { with mild TG elevation }\end{array}$ & $\begin{array}{l}\text { n3 EPA+DHA vs nil, } 6 \text { months, } 1.0 \mathrm{~g} / \mathrm{d} \\
\text { EPA+DHA }\end{array}$ & $\begin{array}{l}\text { Moderate } \\
\text { or high }\end{array}$ \\
\hline $\begin{array}{l}\text { PREDIMED } \\
2013[147-151]\end{array}$ & $\begin{array}{l}\text { Men ( } 55-80 \text { years) \& women } \\
\text { ( } 60-80 \text { years), free of CVD but } \\
\text { with diabetes or } \geq 3 \text { CVD risk } \\
\text { factors }\end{array}$ & $\begin{array}{l}\text { PUFA vs MUFA, } 60 \text { months, dose } \\
\text { unclear }\end{array}$ & $\begin{array}{l}\text { Moderate } \\
\text { to high }\end{array}$ \\
\hline $\begin{array}{l}\text { Ramirez- } \\
\text { Ramirez } 2013 \\
{[152]}\end{array}$ & $\begin{array}{l}\text { People with relapsing remitting } \\
\text { multiple sclerosis }\end{array}$ & $\begin{array}{l}\text { n3 EPA+DHA vs n6 LA, } 12 \text { months, } \\
0.8 \mathrm{~g} / \mathrm{d} \text { EPA + 1.6g/d DHA }\end{array}$ & $\begin{array}{l}\text { Moderate } \\
\text { or high }\end{array}$ \\
\hline $\begin{array}{l}\text { REDUCE-IT } \\
2018[153,154]\end{array}$ & $\begin{array}{l}\text { People with } \\
\text { hypertriglyceridaemia, and } \\
\text { with CVD or with DM and } \\
\text { another risk factor, and on } \\
\text { statin }\end{array}$ & $\begin{array}{l}\text { LCn3 vs paraffin oil, median } 4.9 \text { years, } \\
3.99 \mathrm{~g} / \mathrm{d} \text { EPA }\end{array}$ & $\begin{array}{l}\text { Moderate } \\
\text { or high }\end{array}$ \\
\hline Reed 2014 [45] & Adults with RA & $\begin{array}{l}\text { n3 EPA+DHA vs n6 GLA, } 18 \text { months, } \\
2.1 \mathrm{~g} \mathrm{EPA} \mathrm{+} 1.4 \mathrm{~g} \text { DHA }\end{array}$ & Low \\
\hline $\begin{array}{l}\text { Sandhu } 2016 \\
{[155]}\end{array}$ & $\begin{array}{l}\text { Healthy postmenopausal } \\
\text { women with high breast } \\
\text { density }\end{array}$ & $\begin{array}{l}\text { n-3 vs nil, } 24 \text { months, } 1.86 \mathrm{~g} / \mathrm{d} \text { EPA + } \\
1.5 \text { g/d DHA }\end{array}$ & $\begin{array}{l}\text { Moderate } \\
\text { or high }\end{array}$ \\
\hline $\begin{array}{l}\text { Sawada } 2016 \\
{[156]}\end{array}$ & $\begin{array}{l}\text { People with newly-diagnosed } \\
\text { impaired glucose metabolism } \\
\text { and CAD }\end{array}$ & n3 EPA vs nil, 6 months, $1.8 \mathrm{~g} / \mathrm{d}$ EPA & $\begin{array}{l}\text { Moderate } \\
\text { or high }\end{array}$ \\
\hline $\begin{array}{l}\text { Skoldstam } 1992 \\
{[157]}\end{array}$ & People with stable RA & $\begin{array}{l}\text { n3 EPA+DHA vs n6, } 6 \text { months, } 1.8 \mathrm{~g} / \mathrm{d} \\
\text { EPA + } 1.2 \mathrm{~g} / \mathrm{d} \text { DHA }\end{array}$ & $\begin{array}{l}\text { Moderate } \\
\text { or high }\end{array}$ \\
\hline $\begin{array}{l}\text { SO927 } \\
\text { Hershman } 2015 \\
{[158]}\end{array}$ & $\begin{array}{l}\text { Women with early stage breast } \\
\text { cancer receiving an aromatase } \\
\text { inhibitor with musculoskeletal } \\
\text { pain }\end{array}$ & $\begin{array}{l}\text { n3 EPA+DHA vs n6 LA, } 6 \text { months, } \\
3.36 \mathrm{~g} / \mathrm{d} \text { EPA + 1.68g/d DHA }\end{array}$ & $\begin{array}{l}\text { Moderate } \\
\text { or high }\end{array}$ \\
\hline $\begin{array}{l}\text { Tande } 2016 \\
{[159]}\end{array}$ & $\begin{array}{l}\text { Healthy adult volunteers with } \\
\text { BMI } 25-35 \mathrm{~kg} / \mathrm{m}^{2}\end{array}$ & $\begin{array}{l}\text { n3 EPA+DHA vs MUFA, 12months, } \\
\text { unclear dose }\end{array}$ & $\begin{array}{l}\text { Moderate } \\
\text { or high }\end{array}$ \\
\hline Tani 2017 [160] & $\begin{array}{l}\text { People with stable CAD on } \\
\text { statins }\end{array}$ & $\begin{array}{l}\text { n3 EPA+DHA vs nil, } 6 \text { months, } 1.8 \mathrm{~g} / \mathrm{d} \\
\text { EPA+DHA }\end{array}$ & $\begin{array}{l}\text { Moderate } \\
\text { or high }\end{array}$ \\
\hline $\begin{array}{l}\text { Tardivo } 2015 \\
\text { [161] }\end{array}$ & $\begin{array}{l}\text { Postmenopausal women with } \\
\text { metabolic syndrome }\end{array}$ & $\begin{array}{l}\text { n3 EPA+DHA vs nil, } 6 \text { months, } 0.54 \mathrm{~g} / \mathrm{d} \\
\text { EPA + 0.36g/d DHA }\end{array}$ & $\begin{array}{l}\text { Moderate } \\
\text { or high }\end{array}$ \\
\hline $\begin{array}{l}\text { Tartibian } 2011 \\
{[162,163]}\end{array}$ & $\begin{array}{l}\text { Sedentary postmenopausal } \\
\text { women }\end{array}$ & $\begin{array}{l}\text { n3 EPA+DHA vs nil, } 6 \text { months, } 540 \\
\text { mg/d EPA + } 360 \text { mg/d DHA }\end{array}$ & $\begin{array}{l}\text { Moderate } \\
\text { or high }\end{array}$ \\
\hline $\begin{array}{l}\text { THIS DIET } \\
2008 \text { [164] }\end{array}$ & $\begin{array}{l}\text { Recent survivors of first } \\
\text { myocardial infarction }\end{array}$ & $\begin{array}{l}\text { n3 EPA+DHA vs nil, } 24 \text { months, dose } \\
\text { unclear }\end{array}$ & $\begin{array}{l}\text { Moderate } \\
\text { or high }\end{array}$ \\
\hline $\begin{array}{l}\text { Veleba } 2015 \\
{[165]}\end{array}$ & $\begin{array}{l}\text { Overweight/obese type } 2 \mathrm{DM} \\
\text { patients treated with metformin }\end{array}$ & $\begin{array}{l}\text { n3 EPA+DHA vs n6 LA, } 6 \text { months, } \\
0.75 \mathrm{~g} / \mathrm{d} \text { EPA }+2 \mathrm{~g} / \mathrm{d} \text { DHA }\end{array}$ & $\begin{array}{l}\text { Moderate } \\
\text { or high }\end{array}$ \\
\hline $\begin{array}{l}\text { Vijayakumar } \\
2014[166,167]\end{array}$ & $\begin{array}{l}\text { People with stable coronary } \\
\text { artery disease }\end{array}$ & n6 LA vs SFA, 2 years, $15 \%$ E n6 & $\begin{array}{l}\text { Moderate } \\
\text { to high }\end{array}$ \\
\hline $\begin{array}{l}\text { Westberg } 1990 \\
{[168]}\end{array}$ & $\begin{array}{l}\text { Adults with a long-term } \\
\text { systemic lupus erythematosus }\end{array}$ & $\begin{array}{l}\text { n3 EPA vs MUFA, } 6 \text { months, } \sim 3.5 \mathrm{~g} / \mathrm{d} \\
\text { EPA+DHA }\end{array}$ & $\begin{array}{l}\text { Moderate } \\
\text { or high }\end{array}$ \\
\hline $\begin{array}{l}\text { Witte 2012 } \\
{[169-171]}\end{array}$ & $\begin{array}{l}\text { Healthy older adults }(50-80 \\
\text { years) }\end{array}$ & $\begin{array}{l}\text { n3 EPA+DHA vs n6 LA, } 6 \text { months, } \\
1.32 \mathrm{~g} / \mathrm{d} \text { EPA + } 0.88 \mathrm{~g} / \mathrm{d} \text { DHA }\end{array}$ & $\begin{array}{l}\text { Moderate } \\
\text { or high }\end{array}$ \\
\hline
\end{tabular}




\section{Footnotes}

$537 \quad \mathrm{AF}=$ atrial fibrillation

$538 \quad$ ALA = alpha-linolenic acid

$539 \quad \mathrm{BMI}=$ body mass index

$540 \mathrm{CABG}=$ coronary artery bypass grafting

$541 \quad \mathrm{CAD}=$ coronary artery disease

542 CHD $=$ coronary heart disease

$543 \quad \mathrm{CVD}=$ cardiovascular disease

$544 \quad \mathrm{DBP}=$ diastolic blood pressure

545 DHA $=$ docosahexaenoic acid

$546 \quad \mathrm{DM}=$ diabetes mellitus

$547 \quad$ DPA $=$ docosapentaenoic acid

$548 \quad \mathrm{E}=$ dietary energy

549 EPA = eicosapentaenoic acid or icosapentaenoic acid

$550 \mathrm{HDL}=$ high density lipoprotein

551 HRT $=$ hormone replacement therapy

552 HT $=$ hypertension

$553 \quad \mathrm{LA}=$ linoleic acid

554 LCn3 = long-chain omega 3

$555 \mathrm{MI}=$ myocardial infarction

556 MUFA = mono-unsaturated fatty acids

$557 \mathrm{n} 3=$ omega 3

558 n6 = omega 6

559 PUFA $=$ poly-unsaturated fatty acids

$560 \quad$ PTCA $=$ percutaneous

561 RA = rheumatoid arthritis

562 SFA = saturated fatty acids

563 TG $=$ serum triglycerides

564 TIA $=$ transient ischaemic attack

565

566 
SMA, GT, AA, and LH had financial support via the University of East Anglia from the

569 World Health Organization (WHO) for the submitted manuscript. L.H. and A.A. were also 570 funded to attend WHO meetings and present review results; no financial relationships with 571 any organisations that might have an interest in the submitted work in the previous three 572 years.

573

574

575

576

577

578

579

580

581

582

583

584

585

586

587

588

589

590

591

592

593

594

595 
597 1. Ananthakrishnan AN. (2015) Epidemiology and risk factors for IBD. Nat Rev Gastroenterol 598 Hepatol. 12(4):205.

599 2. Ng SC, Shi HY, Hamidi N, Underwood FE, Tang W, Benchimol EI, et al. (2018) Worldwide 600 incidence and prevalence of inflammatory bowel disease in the 21 st century: a systematic review of 601 population-based studies. Lancet (London, England). 390(10114):2769-78. 10.1016/s0140$602 \quad 6736(17) 32448-0$

603 3. Knowles SR, Graff LA, Wilding H, Hewitt C, Keefer L, Mikocka-Walus A. (2018) Quality 604 of Life in Inflammatory Bowel Disease: A Systematic Review and Meta-analyses_-Part I. 605 Inflammatory bowel diseases. 24(4):742-51. 10.1093/ibd/izx100

606 4. Park KT, Ehrlich OG, Allen JI, Meadows P, Szigethy EM, Henrichsen K, et al. (2019) The 607 Cost of Inflammatory Bowel Disease: An Initiative From the Crohn's \&amp; Colitis Foundation. 608 Inflammatory bowel diseases. 10.1093/ibd/izz104

609 5. Lamb CA, Kennedy NA, Raine T, Hendy PA, Smith PJ, Limdi JK, et al. (2019) British 610 Society of Gastroenterology consensus guidelines on the management of inflammatory bowel 611 disease in adults. Gut.gutjnl-2019-318484. 10.1136/gutjnl-2019-318484

612 6. Moulton CD, Pavlidis P, Norton C, Norton S, Pariante C, Hayee B, Powell N. (2019) 613 Depressive symptoms in inflammatory bowel disease: an extraintestinal manifestation of 614 inflammation? Clin Exp Immunol. 197(3):308-18. 10.1111/cei.13276

615 7. Swan K, Allen PJ. (2013) Omega-3 fatty acid for the treatment and remission of Crohn's 616 disease. Journal of Complementary and Integrative Medicine. 10(1):221-8.

617 8. Innes JK, Calder PC. (2018) Omega-6 fatty acids and inflammation. Prostaglandins Leukot 618 Essent Fatty Acids. 132:41-8. 10.1016/j.plefa.2018.03.004

619 9. Pacheco S, Hillier K, Smith C. (1987) Increased arachidonic acid levels in phospholipids of 620 human colonic mucosa in inflammatory bowel disease. Clin Sci (Lond). 73(4):361-4.

$621 \quad 10.1042 / \operatorname{cs} 0730361$ 
622 10. Naito Y, Ji X, Tachibana S, Aoki S, Furuya M, Tazura Y, et al. (2015) Effects of arachidonic 623 acid intake on inflammatory reactions in dextran sodium sulphate-induced colitis in rats. Br J Nutr. 624 114(5):734-45. 10.1017/s000711451500224x

625 11. Soubières AA, Poullis A. (2016) Emerging biomarkers for the diagnosis and monitoring of 626 inflammatory bowel diseases. Inflammatory bowel diseases. 22(8):2016-22.

627 12. Osei-Bimpong A, Meek J, Lewis S. (2007) ESR or CRP? A comparison of their clinical 628 utility. Hematology. 12(4):353-7.

629 13. Desai D, Faubion WA, Sandborn W. (2007) biological activity markers in inflammatory 630 bowel disease. Aliment Pharmacol Ther. 25(3):247-55.

631 14. Norouzinia M, Chaleshi V, Alizadeh AHM, Zali MR. (2017) Biomarkers in inflammatory 632 bowel diseases: insight into diagnosis, prognosis and treatment. Gastroenterology and hepatology 633 from bed to bench. 10(3):155.

634 15. Lochhead P, Khalili H, Ananthakrishnan AN, Richter JM, Chan AT. (2016) Association 635 between circulating levels of C-reactive protein and interleukin-6 and risk of inflammatory bowel 636 disease. Clinical Gastroenterology and Hepatology. 14(6):818-24. e6.

637 16. Costantini L, Molinari R, Farinon B, Merendino N. (2017) Impact of Omega-3 Fatty Acids 638 on the Gut Microbiota. International journal of molecular sciences. 18(12):2645.

$63910.3390 /$ ijms 18122645

640 17. Hooper L, Abdelhamid A, Brainard J, Deane KHO, Song F. (2019) Creation of a database to 641 assess effects of omega-3, omega-6 and total polyunsaturated fats on health: database and 642 methodology for a set of reviews. BMJ Open. 9(5):e029554. DOI: 10.1136/bmjopen-2019-029554 643 18. Abdelhamid AS, Brown TJ, Brainard JS, Biswas P, Thorpe GC, Moore HJ, Deane KHO, 644 Summerbell CD, Worthington HV, Song F, Hooper L. (2020) Omega-3 fatty acids for the primary 645 and secondary prevention of cardiovascular disease. Cochrane Database Syst Rev. (3):CD003177. 646 10.1002/14651858.CD003177.pub5 
647 19. Abdelhamid AS, Martin N, Bridges C, Brainard JS, Wang X, Brown TJ, et al. (2018)

648 Polyunsaturated fatty acids for the primary and secondary prevention of cardiovascular disease.

649 Cochrane Database Syst Rev. 11:CD012345. DOI: 10.1002/14651858.CD012345.pub3

650 20. Hooper L, Al-Khudairy L, Abdelhamid AS, Rees K, Brainard JS, Brown TJ, et al. (2018)

651 Omega-6 fats for the primary and secondary prevention of cardiovascular disease. Cochrane

652 Database Syst Rev. 11:CD011094. DOI: 10.1002/14651858.CD011094.pub4

653 21. Brainard JS, Jimoh OF, Deane KHO, Biswas P, Donaldson D, Maas K, Abdelhamid AS,

654 Hooper L, PUFAH Group. (2020) Omega-3, Omega-6, and Polyunsaturated Fat for Cognition:

655 Systematic Review and Meta-analysis of Randomized Trials. J Am Med Dir Assoc. online ahead of

656 print. 10.1016/j.jamda.2020.02.022

657 22. Brown TJ, Brainard J, Song F, Wang X, Abdelhamid A, Hooper L. (2019) Omega-3, omega-

658 6, and total dietary polyunsaturated fat for prevention and treatment of type 2 diabetes mellitus:

659 systematic review and meta-analysis of randomised controlled trials. Br Med J. 366:14697. DOI:

$660 \quad 10.1136 / \mathrm{bmj} .14697$

661 23. Deane KHO, Jimoh OF, Biswas P, O'Brien A, Hanson S, Abdelhamid AS, Fox C, Hooper L.

662 (2019) Omega-3 and polyunsaturated fat for prevention of depression and anxiety symptoms:

663 systematic review and meta-analysis of randomised trials. The British Journal of Psychiatry.e-pub

664 ahead of print 24 October 2019. 10.1192/bjp.2019.234

665 24. Abdelhamid A, Hooper L, Sivakaran R, Hayhoe RPG, Welch A, The PUFAH Group. (2019)

666 The Relationship Between Omega-3, Omega-6 and Total Polyunsaturated Fat and Musculoskeletal

667 Health and Functional Status in Adults: A Systematic Review and Meta-analysis of RCTs. Calcified

668 Tissue International. 105:353-72. DOI: 10.1007/s00223-019-00584-3

669 25. Thorpe G, Ajabnoor S, Ahmed Z, Abdelhamid A, Hooper L. (2017) Dietary polyunsaturated

670 fat for prevention and treatment of inflammatory bowel disease. PROSPERO.CRD42017068704. 
671 26. Higgins JP, Green S. Cochrane Handbook for Systematic Reviews of Interventions Version 672 5.1.0 (updated March 2011). Oxford: The Cochrane Collaboration; 2011.

673 27. Grade Working Group. (2004) Grading quality of evidence and strength of recommendations. 674 Br Med J. 328(7454):1490-.

675 28. GRADEpro GDT: GRADEpro Guideline Development Tool. gradepro.org: McMaster 676 University (developed by Evidence Prime, Inc); 2015.

677 29. Review Manager 5 (RevMan 5). Copenhagen: The Nordic Cochrane Centre: The Cochrane 678 Collaboration; 2014.

679 30. Moher D, Liberati A, Tetzlaff J, Altman DG. (2009) Preferred reporting items for systematic 680 reviews and meta-analyses: the PRISMA statement. PLoS Med. 6(7):e1000097.

681 10.1371/journal.pmed.1000097

682 31. Browning LM, Walker CG, Mander AP, West AL, Madden J, Gambell JM, Young S, Wang 683 L, Jebb SA, Calder PC. (2012) Incorporation of eicosapentaenoic and docosahexaenoic acids into 684 lipid pools when given as supplements providing doses equivalent to typical intakes of oily fish. Am 685 J Clin Nutr. 96(4):748-58.

686 32. Higgins JPT, Altman DG, Sterne JAC, Cochrane Statistical Methods Group, Cochrane Bias 687 Methods Group. Chapter 8: Assessing risk of bias in included studies. In: Higgins JPT, Green S, 688 editors. Cochrane handbook for systematic reviews of interventions Version 510 [updated March 689 2011]. Available from www.handbook.cochrane.org: The Cochrane Collaboration; 2011.

690 33. McKenzie JE, Herbison GP, Deeks JJ. (2016) Impact of analysing continuous outcomes 691 using final values, change scores and analysis of covariance on the performance of meta-analytic 692 methods: a simulation study. Research Synthesis Methods. 7(4):371-86. 10.1002/jrsm.1196 693 34. Higgins JP, Thompson SG, Deeks JJ, Altman DG. (2003) Measuring inconsistency in meta694 analyses. Br Med J. 327:557-60. 
695 35. Hoogeveen EK, Geleijnse JM, Kromhout D, Giltay EJ. (2014) No effect of n-3 fatty acids on 696 high-sensitivity C-reactive protein after myocardial infarction: the Alpha Omega Trial. European 697 Journal of Preventive Cardiology. 21(11):1429-36.

698 36. ASCEND Study Collaborative Group. (2018) Effects of n-3 Fatty Acid Supplements in 699 Diabetes Mellitus. N Engl J Med. 379(16):1540-50. 10.1056/NEJMoa1804989

700 37. Belluzzi A, Brignola C, Campieri M, Pera A, Boschi S, Miglioli M. (1996) Effect of an 701 enteric-coated fish-oil preparation on relapses in Crohn's disease. New England Journal of Medicine. $702 \quad 334(24): 1557-60$.

703 38. Clark LF, Thivierge MC, Kidd CA, McGeoch SC, Abraham P, Pearson DW, Horgan GW, 704 Holtrop G, Thies F, Lobley GE. (2016) Fish oil supplemented for 9 months does not improve 705 glycaemic control or insulin sensitivity in subjects with impaired glucose regulation: a parallel 706 randomised controlled trial. Br J Nutr. 115(1):75-86.

707 39. The Dry Eye Assessment and Management Study Research Group. (2018) n-3 Fatty Acid 708 Supplementation for the Treatment of Dry Eye Disease. N Engl J Med. 378(18):1681-90.

709 10.1056/NEJMoa1709691

710 40. Danthiir V, Hosking D, Burns NR, Wilson C, Nettelbeck T, Calvaresi E, et al. (2014)

711 Cognitive performance in older adults is inversely associated with fish consumption but not 712 erythrocyte membrane n-3 fatty acids. J Nutr. 144(3):311-20.

713 41. Edel AL, Rodriguez-Leyva D, Maddaford TG, Caligiuri SP, Austria JA, Weighell W, et al. 714 (2015) Dietary flaxseed independently lowers circulating cholesterol and lowers it beyond the effects 715 of cholesterol-lowering medications alone in patients with peripheral artery disease. J Nutr. 716 145(4):749-57.

717 42. Lorenz-Meyer H, Bauer P, Nicolay C, Schulz B, Purrmann J, Fleig WE, et al. (1996) Omega7183 fatty acids and low carbohydrate diet for maintenance of remission in Crohn's disease. A 719 randomized controlled multicenter trial. Scandinavian Journal of Gastroenterology. 31(8):778-85. 
720 43. Bemelmans WJ, Lefrandt JD, Feskens EJ, van Haelst PL, Broer J, Meyboom-de Jong B, et al.

721 (2004) Increased alpha-linolenic acid intake lowers C-reactive protein, but has no effect on markers

722 of atherosclerosis. Eur J Clin Nutr. 58(7):1083-9.

723 44. Sanders TA, Hall WL, Maniou Z, Lewis F, Seed PT, Chowienczyk PJ. (2011) Effect of low

724 doses of long-chain n-3 PUFAs on endothelial function and arterial stiffness: a randomized

725 controlled trial. Am J Clin Nutr. 94(4):973-80.

726 45. Reed GW, Leung K, Rossetti RG, Vanbuskirk S, Sharp JT, Zurier RB. (2014) Treatment of

727 rheumatoid arthritis with marine and botanical oils: an 18-month, randomized, and double-blind trial.

728 Evid Based Complement Alternat Med. 2014:857456.

729 46. Pot GK, Majsak-Newman G, Geelen A, Harvey LJ, Nagengast FM, Witteman BJ, et al.

730 (2009) Fish consumption and markers of colorectal cancer risk: a multicenter randomized controlled 731 trial. Am J Clin Nutr. 90(2):354-61.

732 47. Almallah YZ, Ewen SW, Mowat NA, Brunt PW, Sinclair TS, Heys Sd et al. (1998)

733 Immunohistological modulation after nutritional supplementation with omega-3 essential fatty acids

734 in patients with inflammatory bowel disease [abstract]. Br J Surg. 85:690-1.

735 48. Greenfield SM, Green AT, Teare JP, Jenkins AP, Punchard NA, Ainley CC, Thompson RP. 736 (1993) A randomized controlled study of evening primrose oil and fish oil in ulcerative colitis.

737 Aliment Pharmacol Ther. 7(2):159-66.

738 49. Hawthorne AB, Daneshmend TK, Hawkey CJ, Belluzzi A, Everitt SJ, Holmes GK, et al. 739 (1992) Treatment of ulcerative colitis with fish oil supplementation: a prospective 12 month 740 randomised controlled trial. Gut. 33(7):922-8.

741 50. Loeschke K, Ueberschaer B, Pietsch A, Gruber E, Ewe K, Wiebecke B, et al. (1996) N-3

742 fatty acids only delay early relapse of ulcerative colitis in remission. Digestive Diseases and

743 Sciences. 41(10):2087-94. 
744 51. Mantzaris GJ, Archavlis E, Zografos C, Petraki K, Spiliades C, Triantafyllou G. (1996) A 745 prospective, randomized, placebo-controlled study of fish oil in ulcerative colitis. Hellenic Journal of 746 Gastroenterology. 9(2):138-41.

747 52. Varghese TJ, Coomansingh D, Richardson S, Brunt PW, Mowat NAG, Eltahir A et al. (2000)

748 Clinical response of ulcerative colitis with dietary omega-3 fatty acids: a double-blind randomized 749 study [abstract]. Br J Surg. 87(1):73-.

750 53. Belluzzi A, Campieri M, Belloli C, Boschi S, Cottone M, Rizzello F, Munarini A, Miglioli 751 M, Williams T, Brignola C. (1997) A new enteric coated preparation of omega-3 fatty acids for 752 preventing post-surgical recurrence in Crohn's disease. Gastroenterology 112(4 (AGA 753 Abstracts)):A930.

754 54. Feagan BG, Sandborn WJ, Mittmann U, Bar-Meir S, D'Haens G, Bradette M, et al. (2008) 755 Omega-3 free fatty acids for the maintenance of remission in Crohn disease: the EPIC Randomized 756 Controlled Trials. JAMA. 299(14):1690-7.

757 55. Mate J, Castanos R, Garcia-Samaniego J, Pajares JM. (1991) Does dietary fish oil maintain 758 the remission of Crohn's Disease (CD): a study case control. Gastroenterology. 100(5, part 2):A228759 A.

760 56. Almallah YZ, El-Tahir A, Heys SD, Richardson S, Eremin O. (2000) Distal procto-colitis and 761 n-3 polyunsaturated fatty acids: the mechanism(s) of natural cytotoxicity inhibition. Eur J Clin 762 Invest. 30(1):58-65.

763 57. Berbert AA, Kondo CR, Almendra CL, Matsuo T, Dichi I. (2005) Supplementation of fish oil 764 and olive oil in patients with rheumatoid arthritis. Nutrition. 21(2):131-6.

765 58. Kromhout D, Giltay EJ, Geleijnse JM, Alpha Omega Trial Group. (2010) n-3 fatty acids and 766 cardiovascular events after myocardial infarction. N Engl J Med. 363(21):2015-26. 
59. Lau CS, Morley KD, Belch JJ. (1993) Effects of fish oil supplementation on non-steroidal anti-inflammatory drug requirement in patients with mild rheumatoid arthritis: a double-blind

769 placebo controlled study. Br J Rheumatol. 32(11):982-9.

770 60. Kristensen S, Schmidt EB, Schlemmer A, Rasmussen C, Lindgreen E, Johansent MB, 771 Christensen JH. (2016) The effect of marine n-3 polyunsaturated fatty acids on cardiac autonomic 772 and hemodynamic function in patients with psoriatic arthritis: a randomised, double-blind, placebo773 controlled trial. Lipids Health Dis. 15:216. 10.1186/s12944-016-0382-5

774 61. Mozaffari H, Daneshzad E, Larijani B, Bellissimo N, Azadbakht L. (2019) Dietary intake of 775 fish, n-3 polyunsaturated fatty acids, and risk of inflammatory bowel disease: a systematic review 776 and meta-analysis of observational studies. Eur J Nutr. 10.1007/s00394-019-01901-0

777 62. Ananthakrishnan AN, Khalili H, Konijeti GG, Higuchi LM, de Silva P, Fuchs CS, Willett 778 WC, Richter JM, Chan AT. (2014) Long-term intake of dietary fat and risk of ulcerative colitis and 779 Crohn's disease. Gut. 63(5):776-84.

780 63. Lev-Tzion R, Griffiths AM, Leder O, Turner D. (2014) Omega 3 fatty acids (fish oil) for 781 maintenance of remission in Crohn's disease. Cochrane Database Syst Rev. (2):Cd006320.

$782 \quad 10.1002 / 14651858 . C D 006320 . p u b 4$

783 64. Lichtenstein GR, Loftus EV, Isaacs KL, Regueiro MD, Gerson LB, Sands BE. (2018) ACG

784 Clinical Guideline: Management of Crohn's Disease in Adults. Am J Gastroenterol. 113(4):481-517. 785 10.1038/ajg.2018.27

786 65. Rubin DT, Ananthakrishnan AN, Siegel CA, Sauer BG, Long MD. (2019) ACG Clinical 787 Guideline: Ulcerative Colitis in Adults. Am J Gastroenterol. 114(3):384-413.

788 10.14309/ajg.0000000000000152

789 66. NICE. Crohn's disease: management. NICE guideline [NG129]. London: National Institute 790 for Health and Care Excellence; 2019. 
791 67. NICE. Ulcerative colitis: management. NICE guideline [NG130]. London: National Institute 792 for Health and Care Excellence; 2019.

793 68. Levine A, Rhodes JM, Lindsay JO, Abreu MT, Kamm MA, Gibson PR, et al. (2020) Dietary 794 Guidance From the International Organization for the Study of Inflammatory Bowel Diseases. Clin 795 Gastroenterol Hepatol. 18(6):1381-92. 10.1016/j.cgh.2020.01.046

796 69. Bischoff SC, Escher J, Hébuterne X, Kłęk S, Krznaric Z, Schneider S, Shamir R, Stardelova 797 K, Wierdsma N, Wiskin AE, Forbes A. (2020) ESPEN practical guideline: Clinical Nutrition in 798 inflammatory bowel disease. Clinical Nutrition. 39(3):632-53.

799 https://doi.org/10.1016/j.clnu.2019.11.002

800 70. Menees SB, Powell C, Kurlander J, Goel A, Chey WD. (2015) A Meta-Analysis of the Utility 801 of C-Reactive Protein, Erythrocyte Sedimentation Rate, Fecal Calprotectin, and Fecal Lactoferrin to 802 Exclude Inflammatory Bowel Disease in Adults With IBS. Am J Gastroenterol. 110(3):444-54. $803 \quad 10.1038 /$ ajg.2015.6

804 71. Ghweil A, Khodeary A, Aziz S. (2018) Diagnostic Value of Fecal Calprotectin and Serum 805 MMP-9 in Diagnosing Disease Activity of Ulcerative Colitis. Open Journal of Gastroenterology. 806 8:234-44. 10.4236/ojgas.2018.86026

807 72. Nelson EC, Eftimovska E, Lind C, Hager A, Wasson JH, Lindblad S. (2015) Patient reported 808 outcome measures in practice. BMJ : British Medical Journal. 350:g7818. 10.1136/bmj.g7818 809 73. Ma C, Panaccione R, Fedorak RN, Parker CE, Khanna R, Levesque BG, Sandborn WJ, 810 Feagan BG, Jairath V. (2017) Development of a core outcome set for clinical trials in inflammatory 811 bowel disease: study protocol for a systematic review of the literature and identification of a core 812 outcome set using a Delphi survey. BMJ Open. 7(6):e016146. 10.1136/bmjopen-2017-016146

813 74. Pot GK, Brouwer IA, Enneman A, Rijkers GT, Kampman E, Geelen A. (2009) No effect of 814 fish oil supplementation on serum inflammatory markers and their interrelationships: a randomized 815 controlled trial in healthy, middle-aged individuals. Eur J Clin Nutr. 63(11):1353-9. 
75. Pot GK, Majsak-Newman G, Geelen A, Harvey LJ, Przybylska K, Hart A, et al. (2009) Effect

817 of a fish intervention on markers of colorectal carcinogenesis: The fishgastro study. Gut. 58:A80.

818 76. Bowman L, Aung T, Haynes R, Armitage J. (2012) ASCEND: Design and baseline

819 characteristics of a large randomised trial in diabetes. Diabetes. 61:A556-A7.

820 77. Asbell PA, Maguire MG, Peskin E, Bunya VY, Kuklinski EJ. (2018) Dry Eye Assessment 821 and Management (DREAM@) Study: Study design and baseline characteristics. Contemp Clin 822 Trials. 71:70-9. https://doi.org/10.1016/j.cct.2018.06.002

823 78. Nigam A, Talajic M, Roy D, Nattel S, Lambert J, Nozza A, et al. (2014) Fish oil for the 824 reduction of atrial fibrillation recurrence, inflammation, and oxidative stress. J Am Coll Cardiol. 825 64(14):1441-8.

826 79. Nigam A, Talajic M, Roy D, Nattel S, Lambert J, Nozza A, et al. (2013) Multicentre trial of 827 fish oil for the reduction of atrial fibrillation recurrence, inflammation and oxidative stress: The atrial 828 fibrillation fish oil research study. Can J Cardiol. 1):S383-S.

829 80. Geleijnse JM, Giltay EJ, Schouten EG, de Goede J, Oude Griep LM, Teitsma-Jansen AM, et 830 al. (2010) Effect of low doses of n-3 fatty acids on cardiovascular diseases in 4,837 post-myocardial 831 infarction patients: design and baseline characteristics of the Alpha Omega Trial. Am Heart J. $832 \quad 159(4): 539-46$.

833 81. Araujo CA, Moraes-Fontes MF, Santos L, Riso N. (2014) Omega-3 fatty acids and 834 Mediterranean diet as complimentary therapies for rheumatoid arthritis. Arthritis and Rheumatology. $835 \quad 66:$ S1050.

836 82. Balfego M, Canivell S, Hanzu F, Sala-Vila A, Martinez-Medina M, Murillo S, et al. (2016) 837 Effects of sardine-enriched diet on metabolic control, inflammation and gut microbiota in drug-naive 838 patients wtih type 2 diabetes: a pilot randomized trial. Lipids Health Dis. 15:78. DOI 839 10.1186/s12944-DOI 10.1016-0245-0 
840 83. Belch JJ, Ansell D, Madhok R, O'Dowd A, Sturrock RD. (1988) Effects of altering dietary

841 essential fatty acids on requirements for non-steroidal anti-inflammatory drugs in patients with

842 rheumatoid arthritis: a double blind placebo controlled study. Ann Rheum Dis. 47(2):96-104.

843 84. Bo Y, Zhang X, Wang Y, You J, Cui H, Zhu Y, Pang W, Liu W, Jiang Y, Lu Q. (2017) The

844 n-3 Polyunsaturated Fatty Acids Supplementation Improved the Cognitive Function in the Chinese

845 Elderly with Mild Cognitive Impairment: A Double-Blind Randomized Controlled Trial. Nutrients. 846 9(1):E54-E.

847 85. Brox J, Olaussen K, Osterud B, Elvevoll EO, Bjornstad E, Brattebog G, et al. (2001) A long848 term seal- and cod-liver-oil supplementation in hypercholesterolemic subjects. Lipids. 36(1):7-13.

849 86. Brzeski M, Madhok R, Capell HA. (1991) Evening primrose oil in patients with rheumatoid 850 arthritis and side-effects of non-steroidal anti-inflammatory drugs. Br J Rheumatol. 30(5):370-2.

851 87. Darghosian L, Free M, Li J, Gebretsadik T, Bian A, Shintani A, et al. (2015) Effect of 852 omega-three polyunsaturated fatty acids on inflammation, oxidative stress, and recurrence of atrial 853 fibrillation. Am J Cardiol. 115(2):196-201.

854 88. de Luis D, Domingo J, Izaola O, Casaneuva F, Bellido D, Sajoux I. (2016) Effect of DHA 855 supplementation in a very low-calorie ketogenic diet in the treatment of obesity: a randomized 856 clinical trial. Endocrine. 54:111-22.

857 89. Derosa G, Maffioli P, D'Angelo A, Salvadeo SA, Ferrari I, Fogari E, Gravina A, Mereu R, 858 Randazzo S, Cicero AF. (2009) Effects of long chain omega-3 fatty acids on metalloproteinases and 859 their inhibitors in combined dyslipidemia patients. Expert Opin Pharmacother. 10(8):1239-47.

860 90. Derosa G, Cicero AFG, Fogari E, D'Angelo A, Bonaventura A, Maffioli P. (2011) Effects of 861 n-3 PUFA on insulin resistance after an oral fat load. Eur J Lipid Sci Technol. 113:950-60.

862 91. Blok WL, Deslypere JP, Demacker PM, van-der-Ven JJ, Hectors MC, Van-Der MJ, Katan 863 MB. (1997) Pro- and anti-inflammatory cytokines in healthy volunteers fed various doses of fish oil 864 for 1 year. Eur J Clin Invest. 27(12):1003-8. 
$86592 . \quad$ Deslypere JP. (1992) Influence of supplementation with N-3 fatty acids on different coronary 866 risk factors in men--a placebo controlled study. Verh K Acad Geneeskd Belg. 54(3):189-216.

867 93. Katan MB, Deslypere JP, van BA, Penders M, Zegwaard M. (1997) Kinetics of the 868 incorporation of dietary fatty acids into serum cholesteryl esters, erythrocyte membranes, and 869 adipose tissue: an 18-month controlled study. J Lipid Res. 38(10):2012-22.

870 94. Einvik G, Klemsdal TO, Sandvik L, Hjerkinn EM. (2010) A randomized clinical trial on n-3 871 polyunsaturated fatty acids supplementation and all-cause mortality in elderly men at high 872 cardiovascular risk. Eur J Cardiovasc Prev Rehabil. 17(5):588-92.

873 95. Berstad P, Seljeflot I, Veierod MB, Hjerkinn EM, Arnesen H, Pedersen JI. (2003)

874 Supplementation with fish oil affects the association between very long-chain n-3 polyunsaturated 875 fatty acids in serum non-esterified fatty acids and soluble vascular cell adhesion molecule-1. Clinical 876 Science. 105(1):13-20.

877 96. Hjerkinn EM, Abdelnoor M, Breivik L, Bergengen L, Ellingsen I, Seljeflot I, Aase O, Ole 878 Klemsdal T, Hjermann I, Arnesen H. (2006) Effect of diet or very long chain omega-3 fatty acids on 879 progression of atherosclerosis, evaluated by carotid plaques, intima-media thickness and by pulse 880 wave propagation in elderly men with hypercholesterolaemia. Eur J Cardiovasc Prev Rehabil. 881 13(3):325-33.

882 97. Hjerkinn EM, Seljeflot I, Ellingsen I, Berstad P, Hjermann I, Sandvik L, Arnesen H. (2005) 883 Influence of long-term intervention with dietary counseling, long-chain n-3 fatty acid supplements, 884 or both on circulating markers of endothelial activation in men with long-standing hyperlipidemia. 885 Am J Clin Nutr. 81(3):583-9.

886 98. Lindman AS, Pedersen JI, Hjerkinn EM, Arnesen H, Veierod MB, Ellingsen I, et al. (2004) 887 The effects of long-term diet and omega-3 fatty acid supplementation on coagulation factor VII and 888 serum phospholipids with special emphasis on the R353Q polymorphism of the FVII gene. Thromb 889 Haemost. 91(6):1097-104. 
99. Troseid M, Arnesen H, Hjerkinn EM, Seljeflot I. (2009) Serum levels of interleukin-18 are reduced by diet and n-3 fatty acid intervention in elderly high-risk men. Metabolism. 58(11):1543-9.

100. Ebrahimi M, Ghayour-Mobarhan M, Rezaiean S, Hoseini M, Parizade SM, Farhoudi F, et al. (2009) Omega-3 fatty acid supplements improve the cardiovascular risk profile of subjects with metabolic syndrome, including markers of inflammation and auto-immunity. Acta Cardiologica. 64(3):321-7.

101. Takaki A, Umemoto S, Ono K, Seki K, Ryoke T, Fujii A, et al. (2011) Add-on therapy of EPA reduces oxidative stress and inhibits the progression of aortic stiffness in patients with coronary artery disease and statin therapy: a randomized controlled study. J Atheroscler Thromb. 18(10):85766.

102. Cauley JA, Manini TM, Lovato L, Talton J, Anton SD, Domanchuk K, et al. (2018) The Enabling Reduction of Low-Grade Inflammation in Seniors (ENRGISE) Pilot Study: Screening Methods and Recruitment Results. The Journals of Gerontology: Series A. 74(8):1296-302. 10.1093/gerona/gly204

103. Manini TM, Anton SD, Beavers DP, Cauley JA, Espeland MA, Fielding RA, et al. (2017) ENabling Reduction of Low-grade Inflammation in SEniors Pilot Study: Concept, Rationale, and Design. J Am Geriatr Soc. 65(9):1961-8. 10.1111/jgs.14965

104. Pahor M, Anton SD, Beavers DP, Cauley JA, Fielding RA, Kritchevsky SB, et al. (2018) Effect of Losartan and Fish Oil on Plasma IL-6 and Mobility in Older Persons. The ENRGISE Pilot Randomized Clinical Trial. The Journals of Gerontology: Series A. 10.1093/gerona/gly277 105. Sanyal AJ, Abdelmalek MF, Suzuki A, Cummings OW, Chojkier M. (2014) No significant effects of ethyl-eicosapentanoic acid on histologic features of nonalcoholic steatohepatitis in a phase 2 trial. Gastroenterology. 147(2):377-84.e1.

106. Danthiir V, Burns NR, Nettelbeck T, Wilson C, Wittert G. (2011) The older people, omega-3, and cognitive health (EPOCH) trial design and methodology: a randomised, double-blind, controlled 
915 trial investigating the effect of long-chain omega-3 fatty acids on cognitive ageing and wellbeing in 916 cognitively healthy older adults. Nutr J. 10:117.

917 107. Eschen O, Christensen JH, Mt LAR, Romano P, Sala P, Schmidt EB. (2010) Effects of

918 marine n-3 fatty acids on circulating levels of soluble adhesion molecules in patients with chronic

919 heart failure. Cell Mol Biol (Noisy-le-grand). 56(1):45-51.

920 108. Finnegan YE, Howarth D, Minihane AM, Kew S, Miller GJ, Calder PC, et al. (2003) Plant 921 and marine derived (n-3) polyunsaturated fatty acids do not affect blood coagulation and fibrinolytic 922 factors in moderately hyperlipidemic humans. J Nutr. 133(7):2210-3.

923 109. Kew S, Banerjee T, Minihane AM, Finnegan YE, Muggli R, Albers R, Williams CM, Calder 924 PC. (2003) Lack of effect of foods enriched with plant- or marine-derived n-3 fatty acids on human 925 immune function. Am J Clin Nutr. 77(5):1287-95.

926 110. Caligiuri SP, Aukema HM, Ravandi A, Guzman R, Dibrov E, Pierce GN. (2014) Flaxseed 927 consumption reduces blood pressure in patients with hypertension by altering circulating oxylipins 928 via an alpha-linolenic acid-induced inhibition of soluble epoxide hydrolase. Hypertension. 64(1):539299.

930 111. Caligiuri SP, Rodriguez-Leyva D, Aukema HM, Ravandi A, Weighell W, Guzman R, et al. 931 (2016) Dietary flaxseed reduces central aortic blood pressure without cardiac involvement but 932 through changes in plasma oxylipins. Hypertension. 68(4):1031-8.

933 112. Edel A, Rodriguez-Leyva D, Weighell W, La Vallee R, Aliani M, Guzman R, et al. (2013) 934 Flaxseed lignan metabolites elicit antihypertensive effects in pad patients in the flax-pad trial. Ann 935 Nutr Metab. 63:1339-.

936 113. Rodriguez-Leyva D, Zahradka P, Ramjiawan B, Guzman R, Aliani M, Pierce GN. (2011)

937 The effect of dietary flaxseed on improving symptoms of cardiovascular disease in patients with 938 peripheral artery disease: rationale and design of the FLAX-PAD randomized controlled trial. 939 Contemp Clin Trials. 32(5):724-30. 
940 114. Kanorsky SG, Bodrikova VV, Kanorskaya YUS. (2007) Influence of perindopril,

941 rosuvastatin, or n-3 fatty acids on efficay of antirecurence therapy with sotalol in patients with

942 persistent atrial fibrillation. Kardiologiia. 12:39-44.

943 115. Krebs J, Browning L, McLean N, Rothwell J, Mishra G, Moore C, Jebb S. (2006) Additive

944 benefits of long-chain n-3 polyunsaturated fatty acids and weight-loss in the mangement of

945 cardiovascular disease risk in overweight hyperinsulinaemic women. Int J Obes (Lond). 30:1535-44.

946 116. Kremer JM, Lawrence DA, Petrillo GF, Litts LL, Mullaly PM, Rynes RI, et al. (1995) Effects

947 of high-dose fish oil on rheumatoid arthritis after stopping nonsteroidal antiinflammatory drugs.

948 Clinical and immune correlates. Arthritis Rheum. 38(8):1107-14.

949 117. Kristensen S, Schmidt EB, Schlemmer A, Rasmussen C, Johansent MB, Christensen JH.

950 Beneficial effect of n-3 polyunsaturated fatty acids on inflammation and analgesic use in psoriatic

951 arthritis - a randomised, double-blind, placebo-controlled trial. 2016 ACR/ARHP Annual

952 Meeting2016.

953 118. Kumar P, Strang A, Ho M, Maple C, Radederstoff D, Morley K, Belch J. (2008) The effects

954 of borage oil supplementation on non-steroidal anti-inflammatory drug requirements in patients with

955 rheumatoid arthritis. Journal of Complementary and Integrative Medicine. 5 (1) (no pagination)(23).

956 119. Ho M, Maple C, Bancroft A, McLaren M, Belch JJ. (1999) The beneficial effects of omega-3

957 and omega-6 essential fatty acid supplementation on red blood cell rheology. Prostaglandins Leukot

958 Essent Fatty Acids. 61(1):13-7.

959 120. Leventhal LJ, Boyce EG, Zurier RB. (1993) Treatment of rheumatoid arthritis with

960 gammalinolenic acid. Ann Intern Med. 119(9):867-73.

961 121. Leventhal LJ, Boyce EG, Zurier RB. (1994) Treatment of rheumatoid arthritis with

962 blackcurrant seed oil. Br J Rheumatol. 33(9):847-52. 
963 122. Li D. (2015) Omega-3 polyunsaturated fatty acids and non-communicable diseases: meta-

964 analysis based systematic review. Asia Pacific Journal of Clinical Nutrition. 24(1):10-5.

965 10.6133/apjcn.2015.24.1.21

966 123. Bemelmans WJ, Broer J, Feskens EJ, Smit AJ, Muskiet AJ, Lefrandt JD, et al. (2002) Effect 967 of an increased intake of alpha-linolenic acid and group nutritional education on cardiovascular risk 968 factors: the Mediterranean alpha-linolenic enriched Groningen dietary intervention (MARGARIN) 969 study. Am J Clin Nutr. 75:221-7.

970 124. Martinez GL, Koury JC, Martins MA, Nogueira F, Fischer RG, Gustafsson A, Figueredo 971 CM. (2014) Serum level changes of long chain-polyunsaturated fatty acids in patients undergoing 972 periodontal therapy combined with one year of omega-3 supplementation: a pilot randomized clinical 973 trial. J Periodontal Implant Sci. 44(4):169-77.

974 125. Rock CL, Flatt SW, Pakiz B, Quintana EL, Heath DD, Rana BK, et al. (2016) Effects of diet 975 composition on weight loss, metabolic factors and biomarkers in a 1-year weight loss intervention in 976 obese women examined by baseline insulin resistance status. Metabolism. 65(11):1605-13.

977 126. Moore CS, Bryant SP, Mishra GD, Krebs JD, Browning LM, Miller GJ, Jebb SA. (2006)

978 Oily fish reduces plasma triacylglycerols: a primary prevention study in overweight men and women. 979 Nutrition. 22(10):1012-24.

980 127. Miller M, Sorkin J, Mastella L, Sutherland A, Rhyne J, Donnelly P, Simpson K, Goldberg A. 981 (2016) Poly is more effective than monounsaturated fat for dietary management in the metabolic 982 syndrome: The muffin study. J Clin Lipidol. 10:996-1003.

983 128. Niki T, Wakatsuki T, Yamaguchi K, Taketani Y, Oeduka H, Kusunose K, Ise T, Iwase T, 984 Yamada H, Soeki T, Sata M. (2016) Effects of the addition of eicosapentaenoic acid to strong statin 985 therapy on inflammatory cytokines and coronary plaque components assessed by integrated 986 backscatter intravascular ultrasound. Circ J. 80(2):450-60. 
987 129. Nishio R, Shinke T, Otake H, Nakagawa M, Nagoshi R, Inoue T, et al. (2014) Stabilizing 988 effect of combined eicosapentaenoic acid and statin therapy on coronary thin-cap fibroatheroma. 989 Atherosclerosis. 234(1):114-9.

990 130. Nodari S, Metra M, Milesi G, Manerba A, Cesana BM, Gheorghiade M, Dei Cas L. (2009) 991 The role of n-3 PUFAs in preventing the arrhythmic risk in patients with idiopathic dilated 992 cardiomyopathy. Cardiovasc Drugs Ther. 23(1):5-15.

993 131. Nodari S, Triggiani M, Berlinghieri N, Milesi G, Foresti A, Gheorghiade M, Dei Cas L. 994 (2010) Effects of n-3 polyunsaturated fatty acids on left ventricular function and functional capacity 995 in heart failure patients. Eur Heart J. 31:850.

996 132. Nogueira M, Oliveira C, Alves V, Stefano J, Rodrigues L, Torrinhas R, Cogliati B, Barbeiro 997 H, Carrilho F, Waitzberg D. (2016) Omega-3 polyunsaturated fatty acids in treating non-alcoholic 998 steatohepatitis: A randomized, double-blind, placebo-controlled trial. Clinical Nutrition. 35:578-86. 999 133. Nilsen DW, Albrektsen G, Landmark K, Moen S, Aarsland T, Woie L. (2001) Effects of a 1000 high-dose concentrate of n-3 fatty acids or corn oil introduced early after an acute myocardial 1001 infarction on serum triacylglycerol and HDL cholesterol. Am J Clin Nutr. 74(1):50-6.

1002 134. Heydari B, Abbasi S, Shah R, Abdullah S, Harris W, McConnell J, et al. (2015) Effect of 1003 purified omega-3 fatty acids on reducing left ventricular remodeling after acute my ocardial 1004 infarction (omega-remodel study: A double-blind randomized clinical trial). J Am Coll Cardiol. 1005 1):A1083.

1006 135. Heydari B, Abdullah S, Pottala JV, Shah R, Abbasi S, Mandry D, et al. (2016) Effect of 1007 Omega-3 Acid Ethyl Esters on Left Ventricular Remodeling After Acute Myocardial Infarction: The 1008 OMEGA-REMODEL Randomized Clinical Trial. Circulation. 134:378-91.

1009 136. Heydari B, Abdullah S, Pottala JV, Shah RV, Abbasi SA, Mandry D, et al. (2016) ST2 is 1010 reduced by high-dose omega-3 fatty acid treatment following acute MI and is correlated with 1011 reduction of the extracellular volume fraction of non-infarcted myocardium. Journal of 
1012 Cardiovascular Magnetic Resonance Conference: 19th Annual SCMR Scientific Sessions Los 1013 Angeles, CA United States Conference Start. 18(no pagination).

1014 137. Eriksdotter M, Vedin I, Falahati F, Freund-Levi Y, Hjorth E, Faxen-Irving G, Wahlund LO, 1015 Schultzberg M, Basun H, Cederholm T, Palmblad J. (2015) Plasma Fatty Acid Profiles in Relation to 1016 Cognition and Gender in Alzheimer's Disease Patients During Oral Omega-3 Fatty Acid 1017 Supplementation: The OmegAD Study. J Alzheimers Dis. 48(3):805-12.

1018 138. Faxén Irving G, Freund-Levi Y, Eriksdotter-Jönhagen M, Basun H, Brismar K, Hjorth E, 1019 Palmblad J, Vessby B, Vedin I, Wahlund L, Cederholm T. (2009) N-3 fatty acid supplementation 1020 effects on weight and appetite in patients with Alzheimer's disease: The OmegAD Study. J Am 1021 Geriatr Soc. 57:11-7.

1022 139. Faxén Irving G, Freund-Levi Y, Eriksdotter-Jönhagen M, Basun H, Hjorth E, Palmblad J, 1023 Vedin I, Cederholm T, Lars-Olof Wahlund. (2013) Effects on transthyretin in plasma and 1024 cerebrospinal fluid by DHA-rich n-3 fatty acid supplementation in patients with Alzheimer's 1025 Disease: The OmegAD study. J Alzheimers Dis. 36:1-6.

1026 140. Freund-Levi Y, Basun H, Cederholm T, Faxen-Irving G, Garlind A, Grut M, Vedin I, 1027 Palmblad J, Wahlund LO, Eriksdotter-Jonhagen M. (2008) Omega-3 supplementation in mild to 1028 moderate Alzheimer's disease: effects on neuropsychiatric symptoms. Int J Geriatr Psychiatry. 1029 23(2):161-9.

1030 141. Freund-Levi Y, Hjorth E, Lindberg C, Cederholm T, Faxen-Irving G, Vedin I, Palmblad J, 1031 Wahlund LO, Schultzberg M, Basun H, Eriksdotter Jonhagen M. (2009) Effects of omega-3 fatty 1032 acids on inflammatory markers in cerebrospinal fluid and plasma in Alzheimer's disease: the 1033 OmegAD study. Dement Geriatr Cogn Disord. 27(5):481-90.

1034 142. Freund-Levi Y, Hjorth E, Lindberg C, Cederholm T, Faxen-Irving G, Vedin I, Palmblad J, 1035 Wahlund LO, Schultzberg M, Basun H, Eriksdotter Jönhagen M. (2009) Effects of Omega-3 fatty 
1036 acid on inflammatory markers in CSF and plasma in Alzheimer's disease. The OmegAD study. 1037 Dementia and Geriatric Cognitive Disorders. 27:481-90.

1038 143. Freund-Levi Y, Vedin I, Hjorth E, Basun H, Faxén Irving G, Schultzberg M, et al. (2014) 1039 Effects of supplementation with omega-3 fatty acids on oxidative stress and inflammation in patients 1040 with Alzheimer's disease: The OmegAD Study. J Alzheimers Dis. 42:823-31.

1041 144. Tatsuno I, Saito Y, Kudou K, Ootake J. (2013) Long-term safety and efficacy of TAK-085 in 1042 Japanese subjects with hypertriglyceridemia undergoing lifestyle modification: the omega-3 fatty 1043 acids randomized long-term (ORL) study. J Clin Lipidol. 7(6):615-25.

1044 145. Murphy KJ, Meyer BJ, Mori TA, Burke V, Jackie M, Patch CS, et al. (2007) Impact of foods 1045 enriched with n-3 long chain polyunsaturated fatty acids on erythrocyte n-3 levels and 1046 cardiovascualar risk factors. Br J Nutr. 97(4):749-57.

1047 146. Patch CS, Tapsell LC, Mori TA, Meyer BJ, Murphy KJ, Mansour J, et al. (2005) The use of 1048 novel foods enriched with long-chain n-3 fatty acids to increase dietary intake: a comparison of 1049 methodologies assessing nutrient intake. J Am Diet Assoc. 105(12):1918-26.

1050 147. Estruch R, Ros E, Salas-Salvadó J, Covas M, Corella D, Arós F et al. (2018) Retraction and 1051 republication: Primary prevention of cardiovascular disease with a Mediterranean diet. N Engl J Med $1052 \quad 2013 ;$ 368:1279-90. N Engl J Med. 378:25-.

1053 148. Estruch R, Ros E, Salas-Salvado J, Covas MI, Corella D, Aros F, et al. (2013) Primary 1054 prevention of cardiovascular disease with a Mediterranean diet.[RETRACTED and republished as 1055 Estruch 2018, Erratum appears in N Engl J Med. 2014 Feb 27;370(9):886]. N Engl J Med. 1056 368(14):1279-90.

1057 149. Estruch R. (2010) Anti-inflammatory effects of the Mediterranean diet: the experience of the 1058 PREDIMED study. Proc Nutr Soc. 69(3):333-40. 10.1017/S0029665110001539 
1059 150. Garcia-Arellano A, Ramallal R, Ruiz-Canela M, Salas-Salvado J, Corella D, Shivappa N, et 1060 al. (2015) Dietary Inflammatory Index and Incidence of Cardiovascular Disease in the PREDIMED 1061 Study. Nutrients. 7(6):4124-38.

1062 151. Casas R, Urpi-Sardà M, Sacanella E, Arranz S, Corella D, Castañer O, Lamuela-Raventós R1063 M, Salas-Salvadó J, Lapetra J, Portillo MP, Estruch R. (2017) Anti-Inflammatory Effects of the 1064 Mediterranean Diet in the Early and Late Stages of Atheroma Plaque Development. Mediators of 1065 inflammation. 2017:3674390-. 10.1155/2017/3674390

1066 152. Ramirez-Ramirez V, Macias-Islas MA, Ortiz GG, Pacheco-Moises F, Torres-Sanchez ED, 1067 Sorto-Gomez TE, Cruz-Ramos JA, Orozco-Avina G, Celis de la Rosa AJ. (2013) Efficacy of fish oil 1068 on serum of TNF alpha , IL-1 beta , and IL-6 oxidative stress markers in multiple sclerosis treated 1069 with interferon beta-1b. Oxid Med Cell Longev. 2013:709493.

1070 153. Bhatt DL, Steg G, Brinton EA, Jacobson TA, Miller M, Tardif JC, et al. (2017) Rationale and 1071 design of REDUCE-IT: Reduction of Cardiovascular Events with Icosapent Ethyl-Intervention Trial. 1072 Clinical Cardiology. 40:138-48.

1073 154. Bhatt DL, Steg PG, Miller M, Brinton EA, Jacobson TA, Ketchum SB, et al. (2018) 1074 Cardiovascular Risk Reduction with Icosapent Ethyl for Hypertriglyceridemia. N Engl J Med. 1075 10.1056/NEJMoa1812792

1076 155. Sandhu N, Schetter SE, Liao J, Hartman TJ, Richie JP, McGinley J, et al. (2016) Influence of 1077 Obesity on Breast Density Reduction by Omega-3 Fatty Acids: Evidence from a Randomized 1078 Clinical Trial. Cancer Prev Res. 9(4):275-82.

1079 156. Sawada T, Tsubata H, Hashimoto N, Takabe M, Miyata T, Aoki K, et al. (2016) Effects of 61080 month eicosapentaenoicacid treatment on postprandial hyperglycemia,hyperlipidemia, insulin 1081 secretion ability, and concomitant endothelial dysfunction among newly-diagnosed impaired glucose 1082 metabolism patients with coronary artery disease. An open label, single blinded,prospective 
1083 randomized controlled trial. Cardiovasc Diabetol. 15(1):121. DOI 10.1186/s12933-DOI 10.1016-

1084 0437-y

1085 157. Skoldstam L, Borjesson O, Kjallman A, Seiving B, Akesson B. (1992) Effect of six months 1086 of fish oil supplementation in stable rheumatoid arthritis. A double-blind, controlled study.

1087 Scandinavian journal of rheumatology. 21(4):178-85.

1088 158. Hershman DL, Unger JM, Crew KD, Awad D, Dakhil SR, Gralow J, et al. (2015)

1089 Randomized Multicenter Placebo-Controlled Trial of Omega-3 Fatty Acids for the Control of

1090 Aromatase Inhibitor-Induced Musculoskeletal Pain: SWOG S0927. Journal of Clinical Oncology.

1091 33(17):1910-7.

1092 159. Tande KS, Vo TD, Lynch BS. (2016) Clinical safety evaluation of marine oil derived from 1093 Calanus finmarchicus. Regul Toxicol Pharmacol. 80:25-31.

1094 160. Tani S, Nagao K, Yagi T, Atsumi W, Hirayama A. (2017) Impact of adding eicosapentaenoic 1095 acid to statin therapy on plasma pentraxin 3 level in patients with stable coronary artery disease: a 61096 month, randomized controlled study. Am J Cardiovasc Drugs. 17:49-59.

1097 161. Tardivo AP, Nahas-Neto J, Orsatti CL, Dias FB, Poloni PF, Schmitt EB, Nahas EA. (2015)

1098 Effects of omega-3 on metabolic markers in postmenopausal women with metabolic syndrome.

1099 Climacteric. 18(2):290-8.

1100 162. Tartibian B, Hajizadeh Maleki B, Abbasi A. (2011) Omega-3 fatty acids supplementation 1101 attenuates inflammatory markers following eccentric exercise in untrained men. European Journal of 1102 Pain Supplements. 5 (1):219.

1103 163. Tartibian B, Hajizadeh Maleki B, Kanaley J, Sadeghi K. (2011) Long-term aerobic exercise 1104 and omega-3 supplementation modulate osteoporosis through inflammatory mechanisms in post1105 menopausal women: a randomized, repeated measures study. Nutr Metab. 8:71.

1106 164. Tuttle KR, Shuler LA, Packard DP, Milton JE, Daratha KB, Bibus DM, et al. (2008) 1107 Comparison of low-fat versus Mediterranean-style dietary intervention after first myocardial 
1108 infarction (from The Heart Institute of Spokane Diet Intervention and Evaluation Trial). Am J

1109 Cardiol. 101(11):1523-30.

1110 165. Veleba J, Janovska P, Kuda O, Horakova O, Malinska H, Kazdova L, et al. (2015) Combined

1111 intervention with pioglitazone and N-3 fatty acids in metformin-treated diabetic patients. Obesity

1112 Facts. 8:213.

1113 166. Vijayakumar M, Krishnaan S, Sundram KR, Vasudevan DM, Nandakumar S. (2014) What

1114 oil in patients with established coronory artery disease: outcomes of two year dietary intervention

1115 with coconut oil \& sunflower oil. Indian Heart J. 66:S12.

1116 167. Vijayakumar M, Vasudevan DM, Sundaram KR, Krishnan S, Vaidyanathan K, Nandakumar

1117 S, et al. (2016) A randomized study of coconut oil versus sunflower oil on cardiovascular risk factors

1118 in patients with stable coronary heart disease. Indian Heart J. 68:498-506.

1119 168. Westberg G, Tarkowski A. (1990) Effect of MaxEPA in patients with SLE. A double-blind,

1120 crossover study. Scandinavian Journal of Rheumatology. 19(2):137-43.

1121 169. Witte V, Kerti L, Floel A. (2012) Effects of omega-3 supplementation on brain structure and 1122 function in healthy elderly subjects. Alzheimer's dement. 1):441.

1123 170. Witte AV, Kerti L, Hermannstadter HM, Fiebach JB, Schreiber SJ, Schuchardt JP, et al. 1124 (2014) Long-chain omega-3 fatty acids improve brain function and structure in older adults. Cereb 1125 Cortex. 24(11):3059-68.

1126 171. Kulzow N, Witte AV, Kerti L, Grittner U, Schuchardt JP, Hahn A, et al. (2016) Impact of 1127 Omega-3 Fatty Acid Supplementation on Memory Functions in Healthy Older Adults. J Alzheimers 1128 Dis. 51(3):713-25.

1129 172. Wright S, O'Prey F, McHenry M, Leahey W, Devine A, Duffy E, Johnston D, Finch M, Bell

1130 A, McVeigh G. (2008) A randomised placebo-controlled interventional trial of omega-3-

1131 polyunsaturated fatty acids on endothelial function and disease activity in systematic lupus

1132 erythematosus [abstract]. Ir J Med Sci. 177(Suppl 3):S76. 
1133 